\title{
SANTIAGO: ¿DÓNDE ESTAMOS?, ¿HACIA DÓNDE VAMOS?*
}

\author{
Alexander Galetovic \\ y Pablo Jordán
}

En este estudio se muestra que entre 1940 y 2002 la superficie urbanizada de Santiago se multiplicó casi seis veces, desde 11.017 ha hasta 64.140 ha y el número de habitantes creció desde poco menos de un millón hasta 5,5 millones. Sin embargo, la densidad ajustada (el número de habitantes por hectárea urbanizada) no mostró tendencia y en 2002 era muy parecida a la de 1940 (85,1 hab/ha contra 89,2 hab/ha). Se concluye, así, que Santiago sigue siendo apreciablemente más denso que las ciudades de países desarrollados, aunque es menos denso que las ciudades de países asiáticos de ingresos bajos.

Los autores sostienen que la evolución y crecimiento de la ciudad durante la segunda mitad del siglo veinte ha estado determinada por dos políticas públicas. Una son los programas de vivienda social del Minvu, autor material de buena parte del crecimiento de la ciudad hasta mediados de los años ochenta. La otra es el Plan Regulador

Alexander Galetovic. Doctor en economía, Princeton University. Profesor de la Universidad de los Andes e Investigador del Centro de Estudios Públicos.

Pablo Jordán. Arquitecto, Universidad Católica de Chile. Máster en diseño y planificación urbana, Massachusetts Institute of Technology. Socio de UrbeDiseño y Gestión Urbana.

* Este trabajo corresponde al capítulo II del libro Santiago: Dónde Estamos y Hacia Dónde Vamos, editado por Alexander Galetovic, publicado por el Centro de Estudios Públicos en 2006.

Estudios Públicos, 101 (verano 2006). 
Intercomunal de 1960 (PRIS), que introdujo y planificó las vías intercomunales (las mismas que luego serían concesionadas) y con ellas configuró al Santiago contemporáneo. Estas vías, junto con transporte público abundante, permitieron que la mayor población se repartiera en un área más extensa. Ahora bien, Santiago no se extiende porque "se está comiendo al resto de Chile” (desde el censo de 1952 la fracción de la población urbana chilena que vive en Santiago está fija en poco más de 42\%); tampoco porque a sus habitantes se les regale la infraestructura que demandan (por casi toda la infraestructura se paga); ni tampoco porque se haya eliminado el límite en 1979 (el decreto sólo estuvo vigente por seis años y durante esa década la tasa de crecimiento fue la menor de las últimas seis décadas). Por último — se señala—, es claro que el límite es ineficaz si se trata de contener el crecimiento urbano. La ciudad creció de manera parecida en épocas en que no existía (antes de 1960) y cuando fue aplicado con más o menos rigor. Más aún —advierten los autores- el principal trasgresor ha sido el Minvu, que también es el encargado de fijarlo.

Yo quisiera hacer una pregunta final. ¿Tienen Uds. alguna información respecto a todo esto? Porque a mí me han producido un pánico fenomenal con el tema. ¿Tienen alguna información de que está pasando algo? Porque pareciera que hay un proceso en marcha, que se ha notado desde aquí. Yo, por lo menos, no lo he visto...

(Miguel Ángel López, cerrando un foro sobre Santiago, revista AUCA, 37, 1979)

\section{SANTIAGO Y SU CRECIMIENTO}

$\mathrm{E}_{1}$ l Plano 1 muestra la cuenca de Santiago con sus montañas, vaU lles, ríos y canales. El triángulo rojo al centro señala al Santiago originario poco después de su fundación en 1541; en negro aparece la superficie urbanizada — el territorio cubierto por la ciudad — desde 1890 hasta 2002. Es un hecho que durante el siglo veinte Santiago creció y se extendió aceleradamente: entre 1940 y 2002 la superficie urbana se multiplicó casi seis veces, desde 11.017 ha hasta 64.140 ha, y el número de habitantes creció desde poco menos de un millón hasta más de cinco millones (véase el Cuadro $\left.\mathrm{N}^{\mathrm{o}} 1\right)$. 
PLANO 1:

EL CRECIMIENTO DE SANTIAGO, 1890-2002

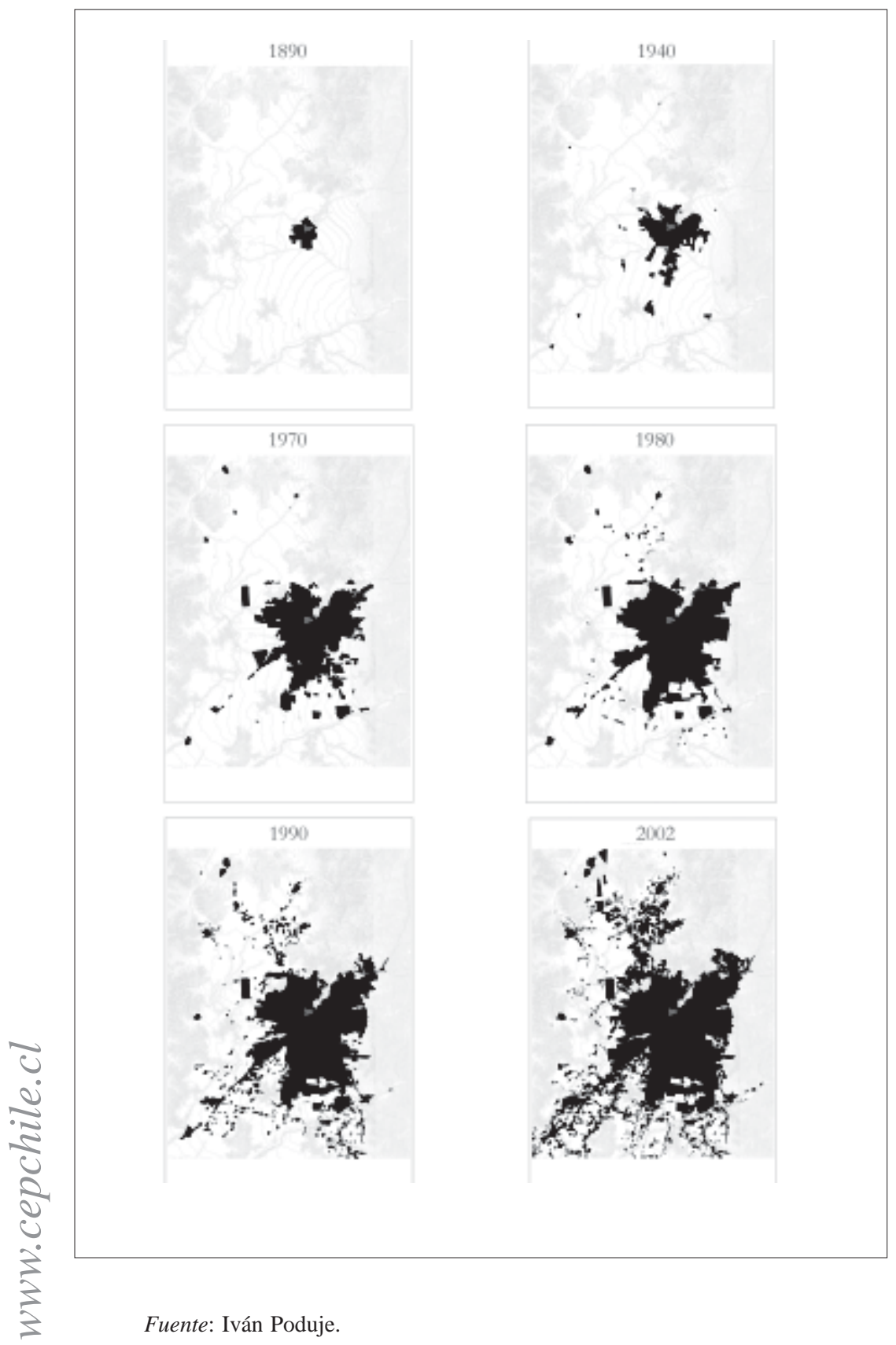




\begin{tabular}{|c|c|c|c|c|c|c|}
\hline & $\begin{array}{c}\text { (1) } \\
\text { Habitantes }^{1}\end{array}$ & $\begin{array}{c}(2) \\
\text { Crecimiento } \\
\text { anual } \\
(\text { tasa \%) })^{2}\end{array}$ & $\begin{array}{l}\text { (3) } \\
\text { Superficie } \\
\text { urbana } \\
(\text { ha })^{1}\end{array}$ & $\begin{array}{c}\text { (4) } \\
\text { Crecimiento } \\
\text { anual } \\
(\mathrm{ha})^{3}\end{array}$ & $\begin{array}{c}\text { (5) } \\
\text { Crecimiento } \\
\text { anual } \\
(\text { tasa \%) }\end{array}$ & $\begin{array}{c}(6) \\
\text { Densidad } \\
\text { (hab./ha) } \\
(1) /(3)\end{array}$ \\
\hline 1940 & 982.893 & 3,21 & 11.017 & 361 & 2,80 & 89,2 \\
\hline 1952 & 1.436 .870 & 4,19 & 15.351 & 727 & 4,10 & 93,6 \\
\hline 1960 & 1.996 .142 & 3,52 & 21.165 & 1.068 & 4,17 & 94,3 \\
\hline 1970 & 2.820 .936 & 2,74 & 31.841 & 853 & 2,35 & 88,6 \\
\hline 1982 & 3.902 .356 & 2,00 & 42.080 & 719 & 1,59 & 92,7 \\
\hline 1992 & 4.754 .901 & 1,39 & 49.270 & 1.487 & 2,67 & 96,5 \\
\hline 2002 & 5.456 .326 & & 64.140 & & & 85,1 \\
\hline
\end{tabular}

Notas: (1) Entre 1940 y 1992 la población y la superficie urbana corresponden a las 32 comunas de la provincia de Santiago más Puente Alto y San Bernardo. En 2002 la población y la superficie urbana son las del Gran Santiago, según fue definido por Alexander Galetovic e Iván Poduje (en Galetovic, ed., 2006, cap. 1): la intersección de la superficie urbana con el área política de las 37 comunas reguladas por el Plan Regulador de 1994. (2) La tasa de crecimiento anual de la población es aquella que, compuesta durante, según corresponda, ocho, diez o doce años, da cuenta de la diferencia de población. Así por ejemplo, entre 1961 y 1970 la tasa de 3,99 por ciento por año se obtiene porque $1.907 .378 \times 1,0399^{10}=2.820 .936$. (3) El crecimiento anual reportado en la columna 3 es el promedio simple de la expansión durante, según corresponda, los ocho, diez o doce años siguientes. Así por ejemplo, el crecimiento anual entre 1941 y 1952, igual a 361 ha por año, se obtuvo de (15.351 ha - 11.017 ha)/12. (4) La tasa de crecimiento anual de la superficie urbana es aquella que, compuesta durante, según corresponda, ocho, diez o doce años, da cuenta de la diferencia de tamaño de las superficies urbanas. Así por ejemplo, entre 1941 y 1952 la tasa de 2,80 por ciento por año se obtiene porque 11.017 ha $\mathrm{x} 1,028^{12}=15.315$ ha.

Fuentes: 1940-1992: Miranda (1997); 2002: Cuadros 2 y 3 de Alexander Galetovic e Iván Poduje (en Galetovic, ed., 2006, cap. 1).

¿Cómo interpretar el crecimiento de Santiago? Sus causas y consecuencias son múltiples, pero parece existir acuerdo en que de un tiempo impreciso a esta parte trae más inconvenientes que beneficios. Por ejemplo, se suele afirmar que Santiago es demasiado grande porque es más extenso que ciudades admirables, más pequeñas y mucho más densas, tales como París o Nueva York. También se dice que su crecimiento habría sido a costa del resto de Chile, y que a cambio los santiaguinos sólo han obtenido contaminación, basura, congestión, segregación y tiempos de traslado crecientes. Para muchos, Santiago vive una crisis permanente que acusa su deterioro progresivo. 
Sin embargo, esta visión negativa se contrapone con la conclusión que emerge de los capítulos del libro Santiago: Dónde Estamos y Hacia Dónde Vamos (A. Galetovic, ed., 2006), un tanto distinta y cautelosamente optimista. En realidad, Santiago no se ha ido deteriorando y su estado actual dista mucho de ser malo. Por el contrario, una mirada panorámica al último medio siglo y, sobre todo, a los últimos 20 años revela signos evidentes de progreso, que debiera continuar en la medida en que Chile siga desarrollándose y la calidad de las políticas públicas mejore de manera sustantiva.

El contraste entre nuestro optimismo cauteloso y el diagnóstico habitual de Santiago en crisis seguramente sorprende y exige una explicación detallada. La finalidad del resto de este trabajo, y en realidad de todos los restantes capítulos del libro Santiago: Dónde Estamos y Hacia Dónde Vamos, es darla. Pero si hay algo que cruza todo este libro es la discrepancia entre lo que creemos sobre la ciudad de Santiago y lo que emerge una vez que tales creencias se contrastan con los hechos. Puesto en términos simples, muchas veces pensamos que Santiago camina hacia el colapso porque creemos cosas que no son así. Parece apropiado, entonces, comenzar sometiendo a escrutinio las creencias en que se sostiene la visión de Santiago en crisis.

\section{DÓNDE (CREEMOS QUE) ESTAMOS}

\section{II.1. El tamaño y crecimiento de Santiago}

No es una exageración decir que hace rato la mayoría opina que Santiago es demasiado grande ${ }^{1}$. Pero ¿grande en relación con qué? Se suele afirmar que el crecimiento de Santiago ha sido a costa del resto de Chile y que su tamaño es excesivo porque supera al de ciudades admirables, más pequeñas y mucho más densas donde la calidad de vida es mejor. Por ejemplo, tiempo atrás un destacado profesional afirmaba:

Es tal [el] frenético crecimiento [de Santiago], y la baja densidad con que éste se ha producido, que París cabe 5 veces en ella, Río de Janeiro, 4 veces y Nueva York, 3.

\footnotetext{
${ }^{1}$ Por ejemplo, véase el número 17 de 1970 de la revista AUCA. Y mucho antes, en 1859, Vicente Pérez Rosales escribía en su Ensayo sobre Chile: "Desgraciadamente, el recinto que ocupa [Santiago] es mucho más grande que lo que debía ser relativamente a su población, la que llega apenas a 100.000 almas, comprendiendo en éstas los arrabales lejanos...”.
} 
El Plano 2 (tomado de Marcial Echenique, en Galetovic, ed., 2006, cap. $3^{*}$ ), permite comparar la superficie urbana de Santiago (en el extremo superior derecho) con la de ocho ciudades muy conocidas, entre ellas París y Nueva York. Los planos, todos a la misma escala, se explican por sí mismos: está claro que París no cabe cinco veces en Santiago ni tampoco tres veces Nueva York; todo lo contrario, es mucho más pequeño que estas ciudades. Esto refleja un hecho más general, a saber: que las 70.183 ha cubiertas por el Gran Santiago y Chacabuco en 2002 están muy lejos de megalópolis tales como Nueva York (768.310 ha), Los Ángeles (509.130 ha) o Tokio (448.000 ha) y aun de ciudades apreciablemente más grandes como París (231.085 ha), Boston (230.820 ha), Sao Paulo (203.800 ha), Melbourne (202.698 ha), Londres (157.829 ha) y varias otras ${ }^{2-3}$. En realidad, la extensión de Santiago y la provincia de Chacabuco se parece a la de ciudades como Adelaida (87.047 ha), Vancouver (74.115 ha), Copenhague (59.928 ha) o Madrid (59.700 ha), ciudades que no destacan por su gran tamaño.

La densidad de Santiago tampoco es baja, al menos comparativamente. El Cuadro No 2 muestra las densidades ajustadas tomadas del estudio de 46 ciudades de Kenworthy y Laube (1999). La columna 1 ("total”) muestra la densidad ajustada en toda el área metropolitana respectiva. En 2002 la densidad en el Gran Santiago era de 85,1 hab/ha, bastante mayor que el promedio de las 13 ciudades estadounidenses (14,2 hab/ha), las siete canadienses (28,5 hab/ha) e incluso las 11 europeas (49,9 hab/ha) o, incluso, Tokio (71 hab/ha). Es necesario llegar a las ciudades de países asiáticos en vías de desarrollo, las que promedian 166,4 hab/ha, para encontrar densidades apreciablemente mayores que las de Santiago.

Por supuesto, la densidad promedio de toda un área metropolitana inevitablemente esconde las variaciones. Si sólo se considera la ciudad cen-

* En este caso, como en otros más adelante, los trabajos corresponden a capítulos del volumen colectivo Santiago ¿Dónde Estamos y Hacia Dónde Vamos?, editado por Alexander Galetovic, cuya tabla de contenidos aparece detallada en las referencias bibliográficas al final de este trabajo. (N. del E.)

${ }^{2}$ El área cubierta por Madrid y Sao Paulo se extrajo de Hack (2000); la de Santiago proviene del Cuadro $N^{\circ}$ 2, de Alexander Galetovic e Iván Poduje (en Galetovic, ed., 2006, cap. 1, p. 13). El resto proviene de Kenworthy y Laube (1999). Salvo Santiago, el área del resto de las ciudades citadas corresponde a la que cubrían en 1990.

${ }^{3} \mathrm{Al}$ lector le podrá parecer que las imágenes de las superficies urbanas de Santiago y Nueva York, hechas a la misma escala, desmienten las superficies reportadas en el texto —70.183 ha contra 768.310 ha-. Claramente, el diámetro de Nueva York no es 11 veces mayor que el de Santiago. Sin embargo, la paradoja desaparece cuando se nota que el diámetro de un círculo de superficie 11 veces mayor que otro es sólo 3,3 veces mayor. 


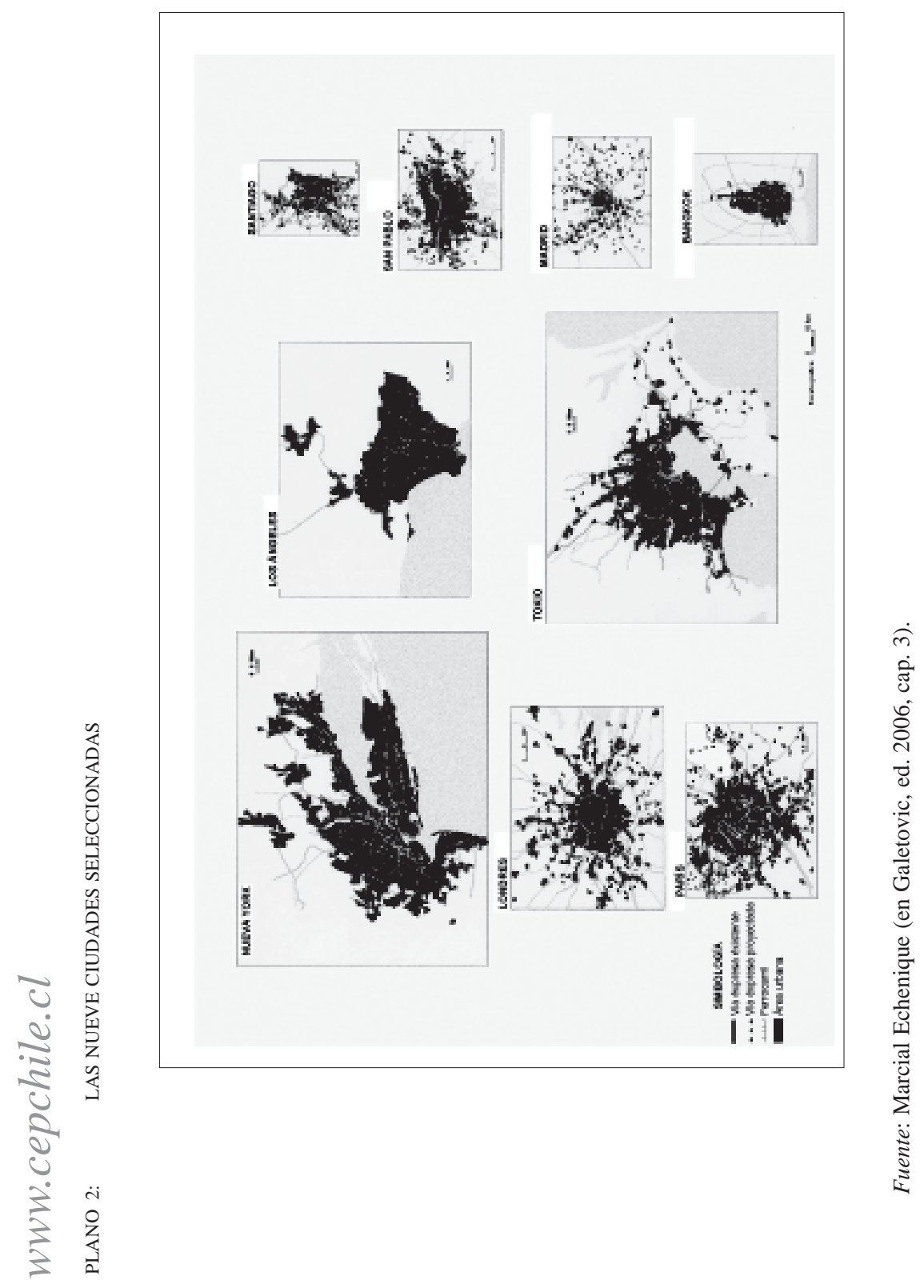




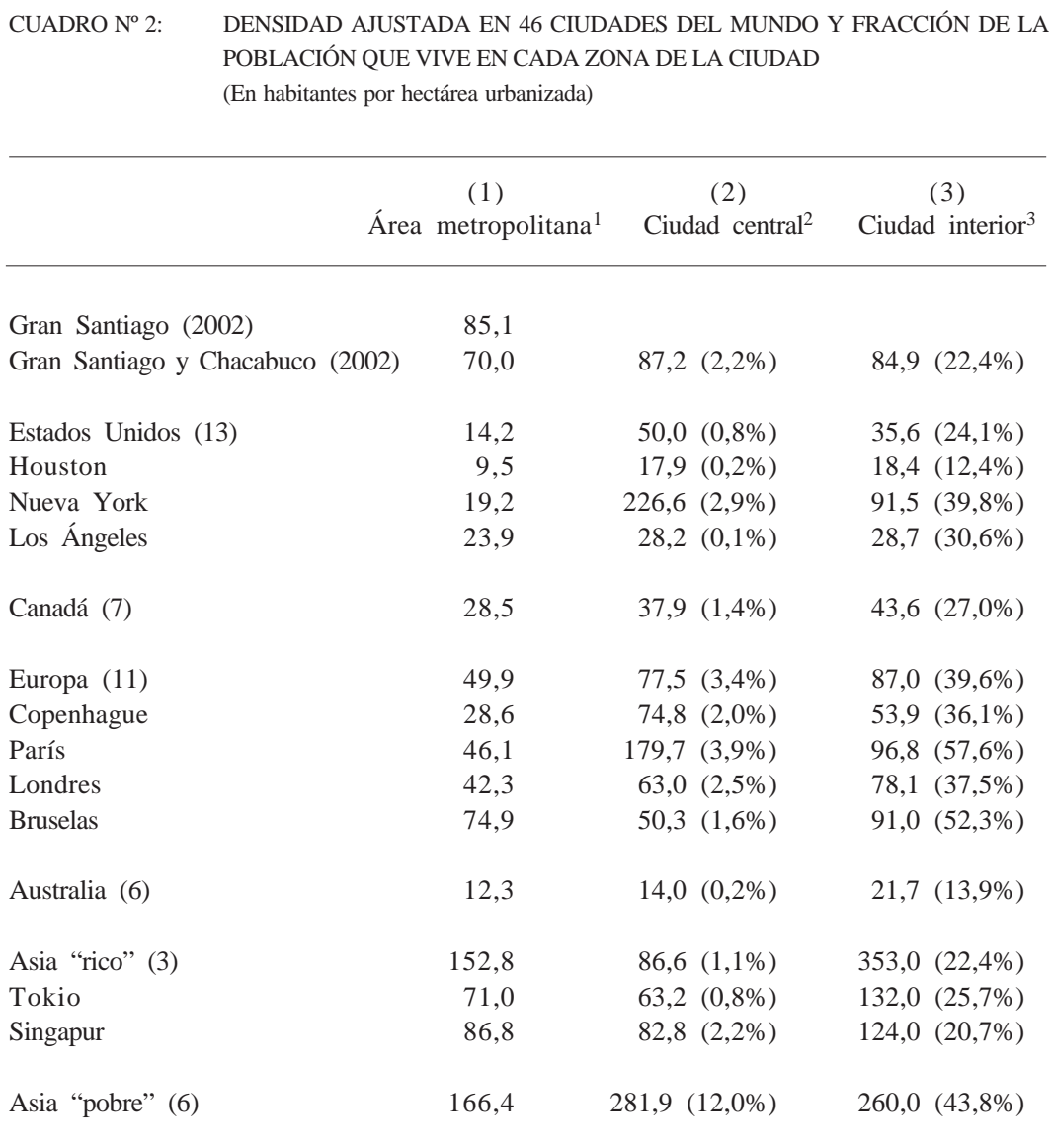

Notas: (1) El área metropolitana se define tan cercana como sea posible al área funcional de una ciudad: el conjunto de distritos, no necesariamente contiguos pero que dependen funcionalmente de la misma área (Kenworthy y Laube, 1999, p. 26). El área del Gran Santiago más la provincia de Chacabuco es la definida en Alexander Galetovic e Iván Poduje (en Galetovic, ed., 2006, cap. 1). (2) La ciudad central corresponde al así llamado Central Business District o CBD (el distrito comercial central), el área de la ciudad con la concentración más alta de empleos (Kenworthy y Laube, 1999, p. 35). En Santiago se definió a la ciudad central como aquella donde se concentran los usos comerciales del suelo. (3) La ciudad interior es la parte del área metropolitana que ya estaba ocupada de manera contigua alrededor de 1939, antes de la masificación del automóvil (Kenworthy y Laube, 1999, p. 32). En Santiago se la definió como aquellos distritos censales de la ciudad que ya estaban cubiertos por la superficie urbana en 1950 (14.383 ha).

Fuentes: La fuente de Santiago es Atisba. La fuente de las 46 ciudades es Kenworthy y Laube (1999), p. 548. 
tral —aquella donde se localiza el principal distrito de negocios—, la densidad suele ser bastante mayor. Así, tal como se muestra en la columna 2, en la ciudad central de Nueva York viven 226,6 habitantes por hectárea y en la de París 179,7, bastante más que los 87,2 hab/ha en Santiago. Pero si bien estas densidades son muy altas, no son representativas: apenas el 2,9 por ciento de los neoyorquinos y el 3,9 por ciento de los parisinos viven en la ciudad central. En otras palabras, la imagen de Nueva York o de París como ciudades muy densas proviene, seguramente, de confundir a Manhattan o la Cité de París (incidentalmente, las áreas que suelen visitar los turistas) con toda el área metropolitana.

También se suele argumentar que Santiago es demasiado grande, que su expansión excesiva ha ido absorbiendo fracciones crecientes de población y actividad económica y le ha ido restando vigor al resto del

GRÁFICO Nº 1: $\quad$ SANTIAGO Y LA POBLACIÓN URBANA, 1952-2002

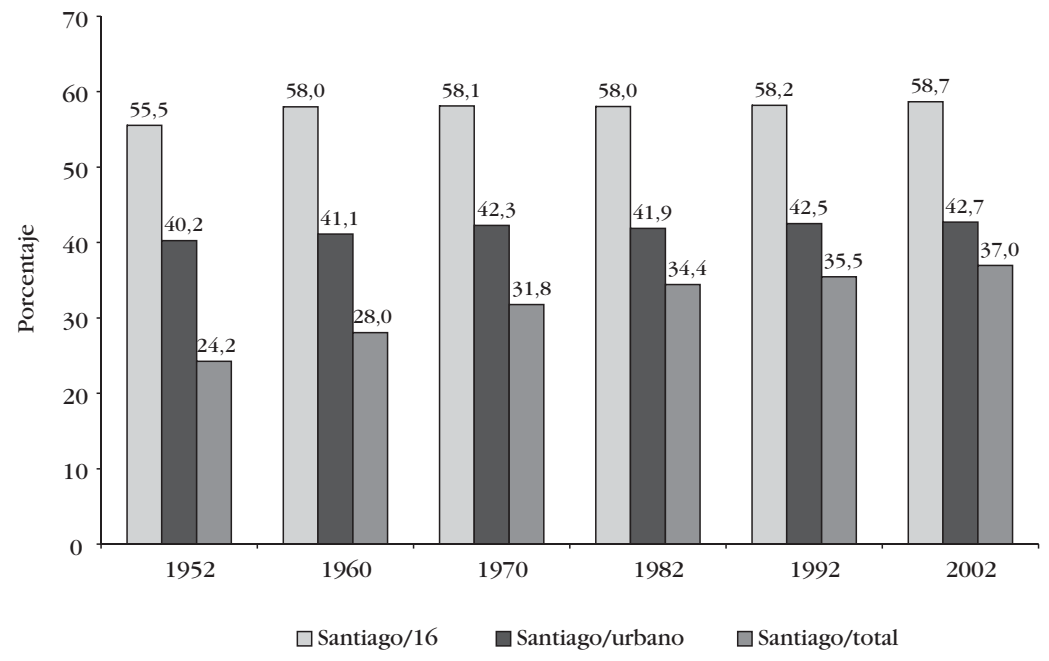

Notas: (1) Las barras “Santiago/16” muestran el porcentaje de la población de las 16 ciudades más grandes de Chile que vivía en Santiago. (2) Las barras "Santiago/ urbano" muestran el porcentaje de la población urbana que vivía en Santiago. (3) Las barras "Santiago/total" muestran el porcentaje de la población de Chile que vivía en Santiago.

Fuentes: La fuente entre 1952 y 1992 es Martínez (1997). La fuente para 2002 es Iván Poduje. En ambos casos, los datos provienen de los censos. 
país ${ }^{4}$. De hecho, las barras en azul oscuro en el Gráfico $N^{\circ} 1$, que muestran la fracción de la población de Chile que vive en Santiago, confirman que con el correr del siglo veinte fue concentrando a una fracción creciente de la población de Chile: mientras en 1952 uno de cada cuatro chilenos vivía en Santiago, tal proporción había aumentado a más de un tercio en 2002.

Sin embargo, las barras en celeste sugieren una interpretación algo distinta. Desde 1952 poco más del 40 por ciento de los chilenos que viven en ciudades reside en Santiago, fracción que casi no ha variado durante más de 50 años $^{5}$. Lo mismo ocurre si consideramos únicamente a los chilenos que viven en las 16 ciudades más grandes de Chile: en 1952 poco más del 55 por ciento vivía en Santiago, fracción que había aumentado un poco, a 58 por ciento en 1960, y no ha variado desde entonces. En realidad, la distribución de la población urbana no ha variado en Chile durante el último medio siglo, hecho que no deja de sorprender habida consideración de los enormes cambios económicos y sociales del período. El gran cambio ocurrido desde los años treinta hasta fines de los setenta fue la migración desde el campo hacia las ciudades y eso hizo aumentar la participación de Santiago. Pero también aumentó la del resto de las ciudades en la misma proporción. La regularidad es que, grosso modo, el crecimiento de la población urbana se reparte por parejo entre todas las ciudades.

Con todo, es innegable que Santiago es grande si se la compara con el resto de las ciudades de Chile. De acuerdo con los World Development Indicators del Banco Mundial, en promedio sólo el 17 por ciento de la población urbana vive en la ciudad más grande de cada país, mientras que en Chile tal proporción llega a 43 por ciento (en Latinoamérica el promedio es 25 por ciento $)^{6}$. Sin embargo, y aunque existe cierta evidencia de que tal nivel de concentración es excesivo y retarda el crecimiento económico, es posible encontrar varios países con primacía similar o aun mayor ${ }^{7}$. Por ejemplo, en 2000 Buenos Aires concentraba el 38 por ciento de la población urbana argentina; Viena el 39 por ciento de la austríaca; Lima el 40 por ciento de la peruana; Dublín el 44 por ciento de la irlandesa; Atenas el 49 por ciento de la griega, y Lisboa el 59 por ciento de la portuguesa ${ }^{8}$.

${ }^{4}$ Véase, por ejemplo, a De Ramón (2000), p. 237 y ss.

${ }^{5}$ Este hecho ya había sido mencionado por Martínez (1997).

${ }^{6}$ Véase Banco Mundial (2004), pp. 152 y ss.

${ }^{7}$ Se le llama primacía a la fracción de la población urbana que vive en el área metropolitana más grande del país.

${ }^{8}$ Véase Banco Mundial (2004), pp. 152 a 154. 


\section{Recuadro 1 El tamaño y la densidad de las ciudades}

El Cuadro $\mathrm{N}^{\circ} 2$ muestra las densidades ajustadas promedio de 46 ciudades de Asia, Europa y América del Norte, extraídas del libro de Kenworthy y Laube (1999). ¿Por qué no presentar las densidades de otras grandes ciudades, sobre todo latinoamericanas?

En la web se pueden encontrar un par de bases con datos de población, superficie y densidad cuya cobertura es apreciablemente más amplia. Sin embargo, éstas no son confiables (de hecho, en algunas, las medidas de Santiago tienen errores gruesos). Esto no debiera sorprender. Kenworthy y Laube inician su estudio explicando que la recolección de datos sobre superficie urbana es difícil. Las metodologías no son estándares, las fechas de recolección no son las mismas y las definiciones de "superficie urbana" varían de ciudad en ciudad. Por ejemplo, algunas reportan como superficie áreas no urbanizadas pero que caen dentro de las zonas administrativas. Otras excluyen lo que queda fuera de la jurisdicción histórica, pero que forma parte de la misma área metropolitana. Así, la única manera de confeccionar una base homogénea es que el investigador viaje y se imponga de los detalles de cada medición in situ. Eso fue lo que hicieron Kenworthy y Laube y por eso es, tal vez, la única fuente confiable de áreas urbanizadas y densidades. Visto esto, preferimos reportar sólo las densidades de estas 46 ciudades.

En un libro como éste también es crucial contar con una medición precisa de la superficie urbana de Santiago y su evolución durante la segunda mitad del siglo veinte. Medidas de la superficie de Santiago aparecen en muchos textos y, grosso modo, son similares. Pero en algunos casos hay discrepancias importantes y por eso es necesario optar por una. A lo largo de todo el libro se usarán las medidas de la superficie reportadas por Miranda (1997) y que se muestran en el Cuadro $\mathrm{N}^{\circ} 1$. En el Apéndice A, al final del libro, se justifica esta elección y se muestran las medidas de la superficie de Santiago provenientes de otros estudios.

\section{II.2. ¿Por qué se ha extendido Santiago?}

Con seguridad Santiago se extiende por más de una razón y por lo mismo abundan las explicaciones. Una recurrente es que el crecimiento "en mancha de aceite" de Santiago se debe a la eliminación del límite urbano en 1979 —el notorio DS № 420 de 1979 del Ministerio de la Vivienda (Minvu)—. Varios autores han señalado que propició este tipo de crecimiento al liberar al mercado inmobiliario. Los privados habrían expandido excesivamente la ciudad y por eso la densidad disminuyó fuertemente.

Alexandra Petermann concluye en su trabajo (en Galetovic, ed., 2006, cap. 8) que tal explicación no es sostenible. La expansión rápida de Santiago 
comenzó durante la década del treinta con las migraciones de los trabajadores del salitre que habían quedado desempleados — casi 50 años antes de 1979—; y continuó después del abandono del DS N 420 en 1985 —el decreto estuvo vigente apenas por seis años-. Más aún, no deja de ser un tanto irónico que, como se puede apreciar en el Cuadro $\mathrm{N}^{\circ} 1$, entre 1982 y 1992 la tasa de crecimiento de la superficie urbana (1,59 por ciento por año) haya sido la más lenta de las últimas seis décadas. En realidad, el número de hectáreas agregadas a la superficie urbana durante los años ochenta (719 ha por año) fue el menor desde la década del cincuenta.

Otra explicación de por qué se ha extendido Santiago da vuelta la causalidad: la opción por densidades bajas habría obligado a ocupar más suelo. Por ejemplo, en la memoria explicativa del Plan Regulador Metropolitano de Santiago de 1994 (Minvu, 1994) se afirma:

[Hay] dos claros momentos de decrecimiento de la densidad: el primero entre 1952 y 1960 y el segundo se registra entre 1982 y 1992, correspondiendo ambos a períodos de fuerte crecimiento en extensión de la ciudad.

El problema de tal explicación es que la densidad de Santiago no ha caído. El Gráfico No 2 muestra la densidad ajustada entre 1940 y 2002 y es claro que no muestra tendencia. Grosso modo, la ciudad y su población han crecido a tasa similar, y no deja de sorprender que en 2002 la densidad haya sido casi la misma que en 1940.

¿Por qué se cree entonces que la densidad decreciente ha ido extendiendo a Santiago? Tal vez esta creencia se debe a que la población de las comunas centrales ha caído un poco, mientras que ha crecido fuertemente en casi todas las comunas de la periferia ${ }^{9}$. Si la periferia fuera menos densa que el centro, la densidad ajustada de todo Santiago iría cayendo.

Sin embargo, se suele pasar por alto que, salvo en el nororiente de Santiago, las densidades son similares y en algunos casos mayores que en las comunas cercanas al centro ${ }^{10}$. De hecho, Andrea Tokman muestra en su trabajo (en Galetovic, ed., 2006, cap. 17) que, una vez excluidas las seis comunas de ingreso per cápita más alto, la densidad residencial (el número

${ }^{9}$ Véase, por ejemplo, el Gráfico № 2 de Iván Poduje (en Galetovic, ed., 2006, cap. 19, p. 254), que muestra la variación de la población de 34 comunas del Gran Santiago entre 1982 y 1992; y el Plano 6 de Alexander Galetovic e Iván Poduje (en Galetovic, ed., 2006, cap. 1), p. 17.

${ }^{10}$ Esto se aprecia claramente en el Plano 7 de Alexander Galetovic e Iván Poduje (en Galetovic, ed., 2006, cap. 1, p. 22), que muestra la densidad de cada distrito censal. 
GRÁFICO No 2: $\quad$ DENSIDAD AJUSTADA EN SANTIAGO, 1940-2002

(En habitantes por hectárea urbanizada)

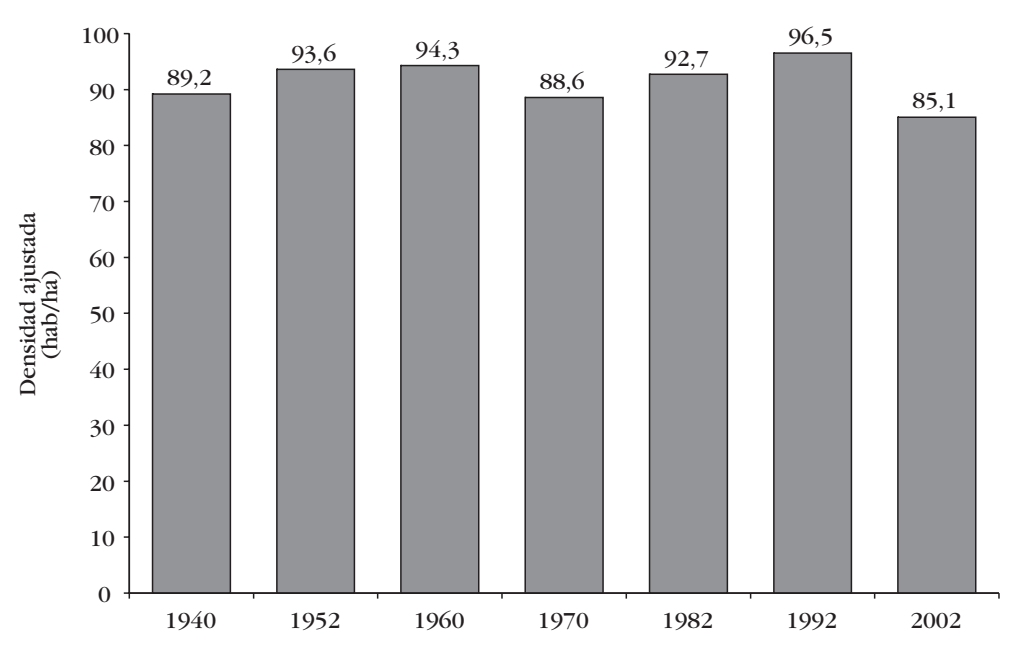

Fuente: Columna 6 del Cuadro $\mathrm{N}^{\mathrm{o}} 1$.

de habitantes por hectárea destinada a residencias) no varía sistemáticamente a medida que uno se aleja de la comuna central de Santiago ${ }^{11}$. En otras palabras, y contrariando la creencia, el crecimiento en extensión no ha sido sinónimo de baja densidad y por eso la densidad no varió mucho durante la segunda mitad del siglo veinte.

También se suele argumentar que Santiago se extiende más de lo conveniente porque los privados no pagan por la infraestructura que los beneficia. Tanto en Chile como en el resto del mundo existe la creencia generalizada de que la extensión de las ciudades genera "demanda excesiva”, es decir, obliga a los gobiernos centrales a financiar infraestructura sin que los beneficiarios la paguen.

Felipe Balmaceda (en Galetovic, ed., 2006, cap. 6) muestra que, al contrario de lo que se cree, gran parte de las obras que se clasifican como "infraestructura" son provistas y pagadas por privados. Es el caso, por ejemplo, de los servicios básicos (agua, luz y teléfonos), el equipamiento (v.

${ }^{11}$ Lejos, además de la comuna de Santiago, las seis comunas con los ingresos per cápita más altos son Vitacura, Providencia, Las Condes, Lo Barnechea, La Reina y Ñuñoa. 
gr., hospitales y colegios privados, centros comerciales) y parte no despreciable del verde que hay en Santiago ${ }^{12}$. Una buena parte de lo que queda es financiada por las municipalidades con impuestos locales, es decir, por los propios vecinos y comercios de cada comuna. Sólo la vialidad regional e intercomunal principal ha sido provista hasta ahora por el gobierno central a través del Minvu y el Ministerio de Obras Públicas (MOP). Pero Balmaceda muestra que su participación en el total de metros lineales de vías apenas supera el 5 por ciento; el resto de las calles es financiado por las municipalidades y, sobre todo, por las inmobiliarias que urbanizan suelo. Y, en todo caso, desde hace tiempo existe un impuesto específico a los combustibles que obliga a pagar más mientras más se viaja y ya se cobra por usar las vías más importantes — las carreteras urbanas concesionadas-. En resumen, la tesis de que en Santiago "nadie paga por la infraestructura" debe revisarse porque no se ajusta a los hechos.

Balmaceda también desmiente dos creencias muy difundidas, a saber: que la infraestructura de las comunas de ingresos altos es subsidiada, estimulándose así la expansión de la ciudad, y que la densificación cura la demanda excesiva. El hecho es que, con toda probabilidad, las siete comunas de mayor ingreso per cápita probablemente subsidian al resto, pues lo que pagan en contribuciones supera por amplio margen a su gasto en servicios e inversión. La razón es que el así llamado Fondo Común Municipal, al que deben aportar todas las municipalidades, redistribuye una fracción importante de los ingresos de las comunas de ingresos altos. Por eso, si es que existe demanda excesiva por infraestructura en Santiago, ésta emerge en comunas relativamente más pobres que gastan más de lo que les cobran a sus habitantes. Por lo mismo, Balmaceda anota que la densificación de Santiago no cura la demanda excesiva; de hecho, las comunas más pobres son también más densas. El punto es que la demanda por infraestructura es excesiva cuando no se paga por ella, sea o no densa la comuna donde ello ocurra.

En todo caso, la arista sorprendente de la redistribución de los ingresos municipales es que la dotación de infraestructura de las distintas comunas de Santiago es bastante pareja: la cobertura de servicios básicos es casi universal y la cercanía (o lejanía) de los hogares a los distintos tipos de infraestructura es similar en comunas de ingresos altos y bajos ${ }^{13}$. Es un

12 Balmaceda observa que una parte mayoritaria del verde de Santiago está en los antejardines y los árboles emplazados en las platabandas frente a los hogares. Esta vegetación es financiada y mantenida directamente por los vecinos.

${ }^{13}$ Véase el Gráfico No 7 de Felipe Balmaceda (en Galetovic, ed., 2006, cap. 6, p. 171). 
logro que la infraestructura sea apreciablemente menos desigual que la distribución del ingreso. Esto permite resaltar un hecho rara vez notado pero que merece atención: una de las principales diferencias entre las comunas pobres y las de ingresos más altos es el diseño urbano, el ornato y sobre todo la cantidad de verde en las calles. ¿No será hora de forestar las veredas de Santiago, tal como lo sugiere Alejandro Aravena en el prólogo? Tal vez Santiago esconde posibilidades insospechadas de redistribución de bienestar.

\section{II.3. Población, políticas públicas y la expansión de Santiago desde 1940}

Y entonces ¿por qué ha crecido y se ha expandido Santiago? Según señala Marcial Echenique (en Galetovic, ed., 2006, cap. 3), el crecimiento y extensión de las ciudades refleja el de la población y los ingresos. Es bastante evidente que una población más grande requiere más espacio, y así ha sido reconocido, por ejemplo, por los planes reguladores de Santiago desde 1960 en adelante. Por contraste, suele apreciarse menos que, si se trata de explicar el crecimiento de las ciudades, el ingreso importa tanto o más que el crecimiento de la población. Tal como explica Echenique, con el mayor ingreso aumentan las demandas por espacio y movilidad: los grupos de ingresos altos habitan viviendas más grandes con más terreno, viajan más en auto y demandan más servicios intensivos en espacio (v. gr., comercios, salud, entretención, deportes). El terreno es más barato en la periferia que en el centro y eso impulsa la expansión de la ciudad. A medida que un país se desarrolla, por tanto, las ciudades se extienden más de lo que crece la población y la densidad cae.

El comportamiento de la densidad ajustada indica, sin embargo, que la expansión de Santiago entre 1940 y 2002 se le debe casi por completo al crecimiento de la población, porque la superficie urbana se multiplicó 5,8 veces y la población 5,6. ¿Es Santiago anómalo? La evolución del PGB per cápita entre 1950 y 2000 sugiere que, probablemente, no ${ }^{14}$. Hasta mediados de los años ochenta el ingreso per cápita creció muy lento, el porcentaje de la población que vivía por debajo de la línea de la pobreza superaba el 40 por ciento y el automóvil, fundamental para aprovechar las ventajas que

${ }^{14}$ PGB es el acrónimo de producto geográfico bruto, el valor a precios de mercado de todos los bienes y servicios producidos en un país en un año dado. El PGB per cápita es el PGB dividido por la población del país. 
ofrece la periferia, no se masificó. De hecho, Enrique Cabrera, Carlos Díaz y Ricardo Sanhueza (en Galetovic, ed., 2006, cap. 14) muestran que todavía en 1991 el 68,1 por ciento de los viajes motorizados se hacía en microbús o metro, y apenas el 18,5 por ciento en automóvil ${ }^{15}$.

Por supuesto, a pesar de que la densidad ajustada se mantuvo casi constante, es evidente que Santiago cambió muchísimo entre 1940 y 2002. Es imposible entender su evolución sin antes estudiar tres políticas públicas que fueron determinantes: la de vivienda social, el Plan Regulador Intercomunal de 1960 y la liberalización del transporte público durante los años setenta.

La política de vivienda social. La política de vivienda social ha sido determinante por el mero peso de su magnitud. Andrea Tokman (en Galetovic, ed., 2006, cap. 17) apunta que, desde la década de los cincuenta, dos tercios de las viviendas entregadas cada año en Chile fueron construidas, encargadas o cofinanciadas por el Estado ${ }^{16}$. Por eso, no sorprende que Alexandra Petermann (en Galetovic, ed., 2006, cap. 8) muestre con varios planos el autor material de buena parte de la expansión de Santiago entre 1960 y hasta la década de los ochenta fue el Estado al actuar como inmobiliaria a través del Minvu.

El peso de la vivienda pública no es sino reflejo de que la redistribución de ingreso a través de programas de vivienda social es de larga data en Chile — Tokman señala que ya en 1906 el gobierno subsidiaba arriendos para proveer viviendas adecuadas para familias pobres-. Y aquí está la clave para entender por qué la densidad se ha mantenido constante. El bajo ingreso per cápita de Chile durante casi todo el siglo veinte, y aún hoy en día, implica que tanto el tipo y tamaño de las viviendas a las que puede acceder la mayoría de los hogares en Chile, así como la velocidad a la que se construyen, dependen fundamentalmente de cuánto está dispuesto a gastar

${ }^{15}$ Marcial Echenique (en Galetovic, ed., 2006, cap. 3) muestra que la tasa de motorización de Santiago es anormalmente baja en relación al PGB per cápita de Chile. En 1990 había en Santiago 76 vehículos motorizados por cada 1.000 habitantes, tasa muy por debajo de la de ciudades de países desarrollados e incluso apreciablemente menor de lo esperable dado el PGB per cápita de Chile en 1990.

${ }^{16}$ Hasta mediados de los años setenta, el Estado construía viviendas. Desde entonces la construcción la contrata con empresas privadas mediante licitaciones competitivas o bien se entregan certificados (los así llamados vouchers) que los beneficiarios ocupan para adquirir viviendas en el mercado abierto. Para una historia breve de los programas habitacionales véase Andrea Tokman (en Galetovic, ed., 2006, cap. 17) y también Castañeda (1992, cap. 4). Una historia extensa de la vivienda social en Chile se encuentra en Hidalgo (2005). 
y subsidiar el Estado. Y el Estado ha decidido su gasto principalmente en función del déficit habitacional, cuya magnitud ha permanecido, grosso modo, proporcional al de la población y sólo comenzó a caer durante los años noventa ${ }^{17}$. Una vez reconocido este mecanismo, la densidad relativamente constante de Santiago es casi inevitable, puesto que el tamaño de las viviendas que se pueden adquirir con subsidios públicos no ha variado mucho — siempre han sido y continúan siendo pequeñas-.

La política de vivienda social ha sido exitosa como programa de redistribución del ingreso hacia familias pobres. Gracias a ella obtuvieron viviendas los hogares que no podían pagarlas y se evitó que el déficit habitacional aumentara, aun durante las décadas en que Chile creció lentamente y el ingreso per cápita permaneció bajo. Por eso, al comparar el Santiago de hoy con el de los años cincuenta o sesenta, se aprecia el gran logro que supone que prácticamente todos los hogares tengan electricidad, agua potable y alcantarillado ${ }^{18}$.

Pero, al mismo tiempo, desde que fuera creado en 1965, el Minvu ha hecho política habitacional ignorando casi completamente sus efectos urbanos, los que han sido considerables y a veces dañinos. El más importante de ellos, tal vez, es el sesgo "perificador". Andrea Tokman sostiene que las poblaciones de viviendas sociales fueron construidas demasiado lejos del centro y estima que si los hogares beneficiados con el subsidio hubieran podido elegir dónde vivir, se habrían localizado alrededor de 1,6 km más cerca del centro.

¿Qué explica este sesgo “perificador”? La causa directa es el método que ocupa el Minvu para decidir dónde localizar sus viviendas, que sólo considera el precio del suelo y el costo de construcción. No incluye las inversiones que recaen en las municipalidades u otros ministerios, ni tampoco el costo del tiempo que deben destinar los hogares beneficiados con el subsidio para trasladarse hacia los lugares de estudio o trabajo. Ese criterio hace casi inevitable que los proyectos se localicen en la periferia, donde el precio del suelo es, tal como lo muestra Tokman, apreciablemente menor porque no cuenta con infraestructura y el resto de la ciudad es menos accesible $^{19}$

El fondo del problema, sin embargo, es que si bien al Minvu se le pide que sea inmobiliaria y regulador urbano, a los ministros se les juzga en

${ }^{17}$ Véase Cummings y Di Pascuale (2002), p. 204.

${ }^{18}$ Felipe Balmaceda (en Galetovic, ed. 2006, cap. 6) apunta que el 99,8 por ciento de los hogares de la Región Metropolitana tiene electricidad, el 99 por ciento tiene agua potable y el 92 por ciento alcantarillado.

19 Tokman (en Galetovic, ed., 2006, cap. 17) muestra que, en promedio, el precio de un terreno cae 8 por ciento por cada kilómetro que se aleja del centro. 
gran medida por el número de viviendas que construyen. Por eso, en sus decisiones el rol de inmobiliaria casi siempre ha tenido preferencia ${ }^{20}$.

La tensión entre los dos roles y la prioridad del rol inmobiliario se refleja claramente en la evolución del límite urbano de Santiago. En el discurso, explica Alexandra Petermann (en Galetovic, ed., 2006, cap. 8), la finalidad del límite urbano ha sido casi siempre contener la expansión de la ciudad. Sin embargo, desde que fuera trazado por primera vez en 1960, el Minvu lo amplió cada vez que ha necesitado más suelo para construir viviendas. Por eso, desde 1960 y hasta mediados de los años noventa, buena parte del suelo incorporado a la ciudad estaba hacia el poniente y sobre todo al sur, donde se ubicaron la mayoría de las viviendas sociales. En realidad, Petermann detecta un patrón detrás de las sucesivas ampliaciones del límite: el Minvu fijaba un límite, generalmente dejando cierto espacio para construir por un par de años; a medida que el terreno se iba ocupando y el Minvu necesitaba más espacio para construir viviendas, ampliaba el límite; el nuevo límite incorporaba las trasgresiones pasadas y dejaba espacio para unos años más. Esta práctica ya no es necesaria, porque a partir de 2003 el artículo N 55 de la Ley General de Urbanismo y Construcciones permite construir viviendas sociales más allá del límite ${ }^{21}$.

La prioridad de la construcción de viviendas también explica los estándares urbanos insuficientes impuestos a los proyectos. Como ya se dijo, al evaluar sus proyectos el Minvu sólo considera el precio del suelo y el costo de la construcción, más no el costo de las inversiones adicionales que deben ejecutar otros ministerios y los propios privados para mitigar los impactos urbanos de las viviendas sociales. Esto contrasta con la evolución de las exigencias que deben cumplir los grandes proyectos inmobiliarios privados que, como describe Iván Poduje (en Galetovic, ed., 2006, cap. 9), deben pagar por cada uno de los impactos viales y ambientales que generan. En apariencia, parece paradójico que el propio regulador urbano le imponga estándares insuficientes a su inmobiliaria. Pero la paradoja desapa-

${ }^{20}$ De hecho, el Minvu fue creado en 1965 para asignarle las funciones inmobiliarias que hasta ese entonces cumplía la Corporación de la Vivienda (Corvi). A cargo del Minvu quedaron la Corporación de Mejoramiento Urbano (Cormu), responsable de comprar suelo; la Corporación Habitacional (Corhabit), responsable de distribuir las viviendas construidas por la Corvi; y la Corporación de Obras Urbanas (COU), a cargo de construir las veredas y alcantarillados de los nuevos proyectos de la Corvi. La Corvi, que había sido creada en 1953, quedó a cargo sólo de construir viviendas.

${ }^{21} \mathrm{El}$ artículo permite construir conjuntos habitacionales de viviendas sociales o de viviendas de hasta un valor de UF 1.000 que cuenten con los requisitos para obtener el subsidio del Estado. 
rece cuando se aprecia que el Minvu responde fundamentalmente a sus intereses de inmobiliaria y actúa tal como lo haría una privada a quien se le dejara imponer sus propias reglas. Estos estándares menos exigentes le permiten al Minvu construir más viviendas con el mismo presupuesto.

El PRIS de 1960 y el transporte público. La política de vivienda social fue la causa material de una buena parte de la "perificación" de Santiago. Pero seguramente ésta no habría sido posible sin el Plan Regulador Intercomunal de Santiago (PRIS) de 1960 y su continuación: el plan de autopistas y ferrocarriles suburbanos de 1970, y sin la fuerte expansión del transporte público, primero a través de la Empresa de Transportes del Estado y, desde fines de los años setenta, a consecuencia de su liberalización.

Iván Poduje (en Galetovic, ed., 2006, cap. 9) muestra que prácticamente todas las vías intercomunales y una buena parte de las avenidas fueron planificadas entonces y se han ido construyendo durante los siguientes cuarenta años ${ }^{22}$. Estas vías, y sobre todo el anillo Circunvalación Américo Vespucio, permitieron distribuir a la población creciente de Santiago y fueron funcionales a la política de vivienda social y su extensión de la ciudad. Esto no fue casualidad, tal como lo explica Iván Poduje. El PRIS se hizo anticipando que la población de Santiago crecería y planificó las inversiones en vías y estimó las de vivienda pública que serían necesarias para acomodarla y distribuirla ${ }^{23}$.

Al mismo tiempo, por estas vías circularon los microbuses, que entraron en gran número desde $1979^{24}$. Es difícil exagerar la importancia que esto ha tenido para el desarrollo de la política de vivienda social. Porque entre los muchos defectos del transporte público santiaguino ciertamente no se cuenta la cobertura insuficiente. Felipe Balmaceda (en Galetovic, ed., 2006, cap. 6) apunta que el 98 por ciento de los hogares de Santiago está a menos de ocho cuadras de un paradero de micros; y Guillermo Díaz, Andrés Gómez-Lobo y Andrés Velasco (en Galetovic, ed., 2006, cap. 15) muestran que el tiempo promedio de espera de una micro en Santiago es de cuatro minutos y sólo el 18 por ciento de los viajes requiere transbordo. Así, y aunque los viajes pueden ser muy largos, en la gran mayoría de los casos es

\footnotetext{
${ }^{22}$ Entre estos ejes se cuentan el anillo Dorsal y la extensión de las avenidas La Florida y Vicuña Mackenna. Más detalles se encuentran en Parrochia y Pavez (2001).

${ }^{23}$ Según Juan Parrochia, uno de los diseñadores del plan, durante los estudios que se hicieron para diseñar el PRIS se había comprobado que nunca había tenido éxito tratar de impedir el crecimiento de una ciudad (véase Pavez, 2003,) p. 234.

${ }^{24}$ Guillermo Díaz, Andrés Gómez-Lobo y Andrés Velasco (en Galetovic, ed., 2006, cap. 15) muestran que entre 1979 y 1990 el número de micros aumentó desde poco más de 5.000 hasta más de 13.000 .
} 
posible llegar desde un punto de Santiago a cualquier otro pagando un solo pasaje. Seguramente esto le permitió al Minvu decidir las inversiones sin preocuparse mayormente de las necesidades de transporte —las micros llegaban solas, siguiendo a las nuevas poblaciones de vivienda social-.

¿Qué habría ocurrido si no se hubieran planificado ni construido las vías intercomunales? Seguramente la población de Santiago habría crecido más o menos lo mismo, pero habría sido físicamente imposible distribuir a igual número de hogares en la periferia sur y poniente en poblaciones de viviendas sociales. Así, la ciudad no habría crecido tanto en extensión sino que hacia adentro, y en vez de mantenerse constante, la densidad habría aumentado.

Por mucho tiempo se han promovido las virtudes de la vida más densa, y de acuerdo con esta visión tal vez habría sido mejor no construir las vías intercomunales. Pero un momento de reflexión sugiere que el resultado habría sido el hacinamiento $\mathrm{y}$, probablemente, un déficit habitacional mucho mayor. Aquí es conveniente notar que en muchas comunas de Santiago ya se vive muy densamente. El Gráfico No 3 muestra, con triángulos celestes, las densidades ajustadas de cada una de las 37 comunas del Gran
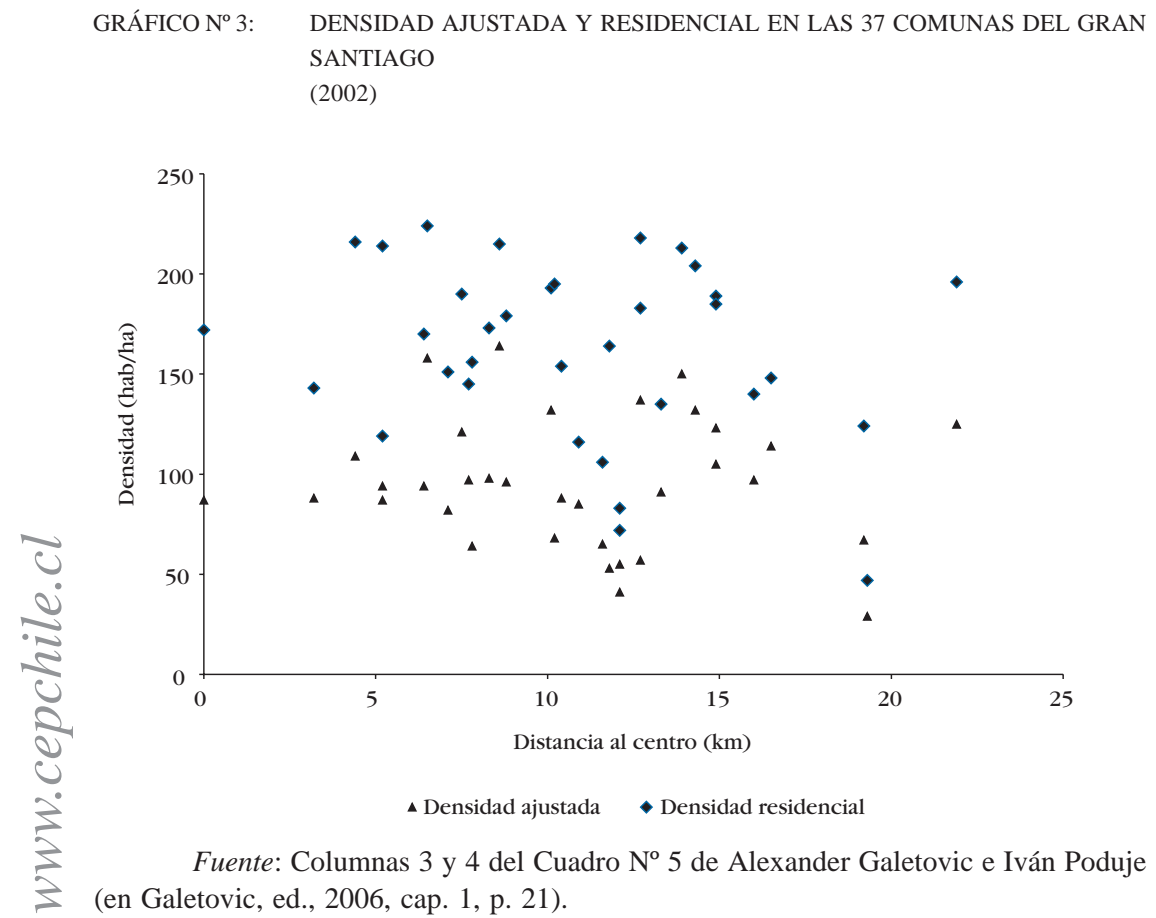
Santiago (ordenadas según su distancia al centro) en 2002; y, con cuadrados azules, las densidades residenciales (el cociente de la población y el área cubierta por residencias), una medida más apropiada de cuán densamente se vive. La densidad residencial es bastante más alta que la densidad ajustada (142 hab/ha contra 85 hab/ha) y se empina muy por encima del promedio en comunas tales como Quilicura (193), Puente Alto (196), La Granja (204), Pudahuel (214), Cerro Navia (215), Lo Espejo (218) o Lo Prado (224), donde se han construido muchas viviendas sociales.

Al mismo tiempo, es improbable que se hubieran podido construir viviendas sociales a la misma tasa que en la periferia. La razón es simple: para densificar las comunas centrales hay que comprar lo que ya existe, demolerlo y construir en altura, lo que cuesta bastante más que las UF 300 de una vivienda básica; sin considerar que muchas veces la infraestructura no es "preexistente" y hay que reparar o incrementar la capacidad de las redes de servicios. Por eso, si no se hubieran planificado las vías intercomunales, las densidades residenciales se habrían empinado a 300 o quizás 400 hab/ha, pero sin un número equivalente de viviendas subsidiadas.

\section{II.4. Las (supuestas) consecuencias del crecimiento y expansión de Santiago}

No es una exageración decir que al crecimiento de Santiago se le atribuyen consecuencias indeseables. Por ejemplo, se dice que la contaminación del aire ha empeorado pari passu con la extensión de Santiago; que la congestión es cada vez mayor; y que la basura está creciendo fuera de control. Varios trabajos del libro Santiago: Dónde Estamos y Hacia Dónde Vamos (Galetovic, ed., 2006) sugieren que, a lo menos, es necesario matizar.

Contaminación del aire. Se suele creer que la contaminación del aire necesariamente aumenta cuando Santiago se extiende. Esta creencia se basa en un supuesto simple: mientras más extensa es la ciudad, más largos son los viajes y más se contamina. Así, no sorprende que muchos piensen que la calidad del aire de Santiago empeora año a año.

Sin embargo, Ricardo Katz (en Galetovic, ed., 2006, cap. 12) muestra que la realidad es distinta. El Gráfico $\mathrm{N}^{\circ}$ 4, tomado de su trabajo, muestra que la contaminación, medida por la concentración de partículas de diámetro de 10 micrones o menos (PM10), cayó un tercio durante los años noventa, desde 106 microgramos por metro cúbico $\left(\mathrm{mg} / \mathrm{m}^{3}\right)$ en 1989 hasta $71 \mathrm{mg} /$ $\mathrm{m}^{3}$ en 2000. Esto ocurrió mientras la superficie de Santiago creció 30 por ciento y el número de viajes motorizados 60 por ciento. Más aún, como se 


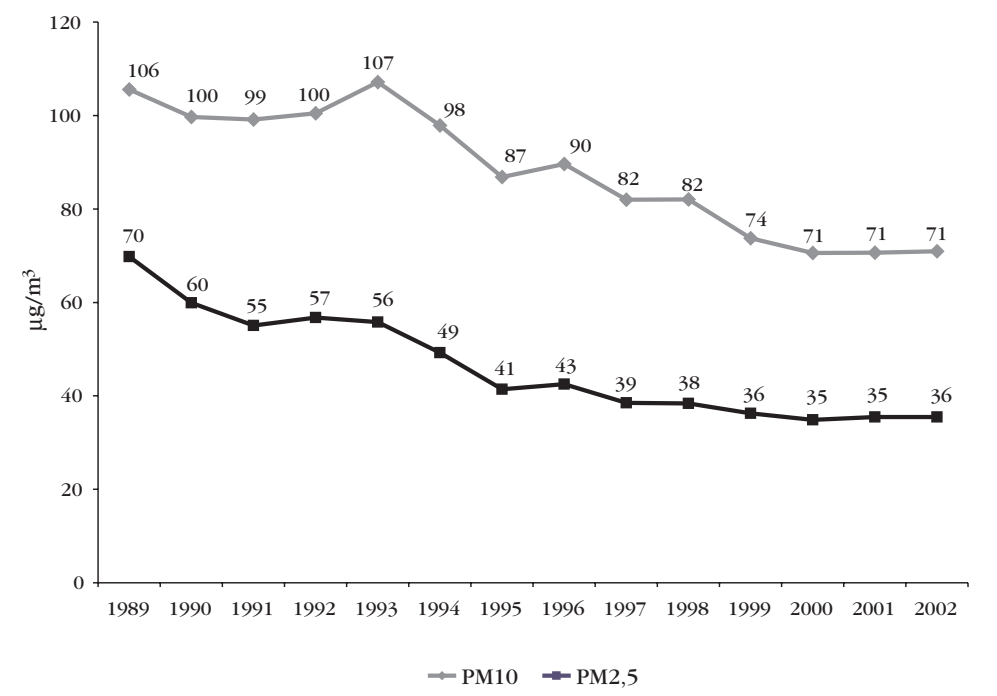

Fuente: Ricardo Katz (en Galetovic, ed., 2006, cap. 12).

aprecia en el gráfico, las partículas más dañinas para la salud, aquellas de 2,5 micrones de diámetro o menos (PM2,5), cayeron a casi la mitad, desde 70 $\mathrm{mg} / \mathrm{m}^{3}$ en 1989 hasta $36 \mathrm{mg} / \mathrm{m}^{3}$ en 2002. Por eso, mientras en $1989 \mathrm{dos}$ tercios del PM10 correspondían a fracción fina, en 2002 la proporción había caído a la mitad.

Este éxito relativo de la política de descontaminación no significa que el problema haya sido resuelto. Si se compara con las ciudades de países desarrollados, Santiago sigue siendo una ciudad contaminada y el PM10 tendría que caer alrededor de 50 por ciento más, a $35 \mathrm{mg} / \mathrm{m}^{3}$, para cumplir con las normas que nos hemos impuesto ${ }^{25}$. Pero, al mismo tiempo, lo ocurrido durante los años noventa muestra que la relación entre tamaño 乙u de la ciudad, número de vehículos y contaminación no es lineal. Esta relaC ción se quiebra con políticas de descontaminación focalizadas que estimu- len la adopción de tecnologías que emitan menos por unidad de actividad.

Por cierto, Katz enfatiza que existe una restricción física fundamental. La emisión total de un contaminante es igual a la suma de las emisiones de las distintas fuentes (v. gr., automóviles, camiones, fábricas, residencias). 3 Para cumplir con las metas es indispensable disminuir la suma total de las 
emisiones. Si bien esto puede parecer obvio, en último término implica que en algún momento podría ser necesario limitar ya sea el número de fuentes o el nivel de actividad de cada una. ¿Cómo es posible, por tanto, que la contaminación haya disminuido con niveles de actividad en aumento? La respuesta, por supuesto, es que hubo vasta sustitución de tecnologías por otras que emiten menos por unidad de actividad.

Por lo mismo, hay razones para pensar que por un buen tiempo no será necesario restringir el crecimiento de la ciudad para lograrlo. En efecto, Katz indica que es perfectamente posible seguir mejorando la calidad del aire con medidas específicas, siempre y cuando se cuente con diagnósticos bastante más precisos que los actuales, y se les dé incentivos directos a los emisores, en vez de aplicar medidas de command and control que predominan hoy en día. Los incentivos permitirían concentrar las reducciones en aquellas fuentes que pueden disminuir las emisiones a menor costo. Un ejemplo sirve para ilustrar las posibles ganancias: Katz (1993) estimó que disminuir en un kilogramo las emisiones de PM2,5 costaba US\$ 500 si se instalaba un lavador de gases en una industria; US\$ 32 si se cambiaba el motor de un microbús; y US\$ 0,50 pavimentando una calle. Las posibilidades de sustituir una fuente más cara por otra más barata apenas se han explotado, porque aún no se han generalizado los permisos de emisión transables. Por eso, es muy probable que hoy se les esté limitando la emisión a quienes les cuesta mucho contaminar menos, al tiempo que hay otros que podrían disminuir sus emisiones a bajo costo, pero que siguen contaminando.

¿Nos estamos ahogando en basura? A juzgar por lo que se ve en las noticias, pareciera que hay pocos problemas más urgentes y difíciles de solucionar que los causados por la basura. Aparentemente, la producción de basura se ha disparado y continuará creciendo a medida que aumenten los ingresos. Pero nadie quiere tener un vertedero cerca de su casa. ¿Qué haremos con tanta basura?

La conclusión más importante de Felipe Zurita (en Galetovic, ed., 2006, cap. 13) es que la basura no es un problema de espacio ni tampoco de recursos. Toda la basura generada por la Región Metropolitana durante un año cabe en un terreno de diez hectáreas (un cuadrado de 316 metros de lado) y el costo anual de disposición es apenas alrededor de 10 dólares por habitante. Además, es razonable esperar que, de ahora en adelante, la cantidad de basura aumente mucho más lentamente que durante los pasados 20 años.

Esta conclusión podría sorprender porque la cantidad de basura ha crecido rápido. En 1980 se depositaba en los vertederos de la Región Metro- 
politana medio kilo diario de basura por habitante. En 2001 esta cifra se había duplicado a un kilo, acercándose a los niveles de países desarrollados. Al mismo tiempo, la población creció 45 por ciento. Así, la basura total depositada en los vertederos se multiplicó por más de tres en los últimos 20 años, lo que equivale a 5,7 por ciento en promedio cada año. Por eso, a primera vista, parecería que por cada punto de crecimiento económico la generación de basura crece 1,2 puntos —entre 1980 y 2001 el PGB creció 4,7 por ciento en promedio cada año-.

Pero Zurita indica que estas proyecciones son equivocadas. ¿Por qué? Alrededor de un tercio del aumento del volumen de basura se debió a la mayor cobertura. En 1980 sólo el 70 por ciento de los desechos terminaba en un vertedero legal, mientras que en la actualidad casi el 100 por ciento se recolecta y entrega en un vertedero legal. Obviamente, no se puede recolectar más que el 100 por ciento y, por ende, disminuirá la tasa de crecimiento medida. De hecho, Zurita estima que la basura aumenta más o menos la mitad de lo que crece el PGB — vale decir, por cada diez puntos de crecimiento del PGB, la basura total debería crecer solamente cinco puntos-.

¿Cuál es el problema, entonces? Zurita sostiene que el revuelo público y los conflictos que causa la basura se deben a que no se han definido los derechos y obligaciones de las comunas. Si, al contrario de lo que ocurre hoy, cada comuna tuviera la obligación de disponer adecuadamente de su propia basura, sería innecesario que una autoridad central decidiera qué comuna debe recibir los desechos del resto. Por cierto, no es fácil crear estas obligaciones — se requieren innovaciones institucionales importantes-, pero al menos debiera reconocerse que la falta de recursos no es la causa de estos problemas.

Transporte, congestión y la expansión de Santiago. En 1991 se hacían en Santiago 5,8 millones de viajes motorizados cada día. De ellos, el 68,1 por ciento era en micro o metro y sólo el 18,5 por ciento en automóviles. Diez años después, en 2001, el número de viajes había aumentado a 9,3 millones. La participación de los automóviles había crecido a 42 por ciento, mientras que la del transporte público había caído a 45,5 por ciento. Este cambio no es sino el reflejo del aumento de la motorización: en 1991 había 93,6 vehículos por cada 1.000 habitantes, mientras que en 2001 ya eran $147,3$.

Estas tendencias preocupan porque muchos estiman que la congestión en Santiago ya es excesiva. Si la ciudad continúa extendiéndose, sigue el argumento, el número de automóviles seguirá aumentando y los costos en tiempo, combustible y contaminación crecerán hasta alcanzar niveles 
intolerables. Construir más vías agravaría el problema, porque el alivio a lo más sería temporal y al poco tiempo habría congestión de nuevo. Y así las políticas apropiadas parecen evidentes: impedir que la ciudad se extienda; encarecer el uso del automóvil mediante la tarificación vial, restricciones y prohibiciones; estimular a que la gente use el transporte público; y regular los usos del suelo para minimizar el número de viajes ${ }^{26}$.

Enrique Cabrera, Carlos Díaz y Ricardo Sanhueza (en Galetovic, ed., 2006, cap. 14) argumentan que es indispensable extender la tarificación vial desde las autopistas urbanas hacia toda la ciudad. Su justificación es conocida. Cuando un vehículo entra a una vía, retrasa al resto. Sin embargo, cada conductor internaliza sólo el costo directo o privado - el tiempo que ocupa en llegar de un punto a otro y el combustible que gasta-. A la diferencia entre el costo social y el privado se le llama externalidad. La finalidad de la tarificación vial es que cada persona que se traslada pague esa externalidad y sólo haga el viaje si está dispuesta a pagar por el costo y las molestias que le genera al resto.

¿Qué se obtiene con la tarificación vial? Si los cobros son apropiados, explican Cabrera, Díaz y Sanhueza, también lo son el número de traslados, la partición modal -la distribución de los viajes entre los distintos modos de transporte - y las horas en que la gente decide viajar. De manera similar, cuando las personas deciden dónde vivir y las empresas dónde ubicarse, tomarán en cuenta las diferencias de costo entre las alternativas: quien decida ubicarse en lugares más alejados pagará más por circular ${ }^{27}$.

Sin embargo, Cabrera, Díaz y Sanhueza desafían algunas creencias sobre qué se debe hacer con la congestión. Para comenzar, argumentan que la tarificación vial apropiada no la eliminaría. Un cierto nivel de congestión no sólo es inevitable sino deseable, porque si se cobrase lo suficiente para que el flujo fuera libre, la gente se trasladaría muy poco. En otras palabras, el problema no es la congestión, sino la congestión excesiva. Tampoco cabe intervenir en las decisiones de cuándo viajar, en qué medio hacerlo o

${ }^{26}$ Buenas compilaciones de estudios que fundamentan este diagnóstico y las propuestas son las de Lanfranco (2003) y el dossier "Cuando Santiago se mueva", contenido en el número 78 (diciembre 2002-febrero 2003) de la Revista Universitaria de la Universidad Católica de Chile.

${ }^{27}$ Cabe mencionar, en todo caso, que desde hace mucho tiempo se aplica un impuesto específico considerable a la bencina —que representa, según el petróleo esté caro o barato, entre un tercio y la mitad del precio final al público- y otro menor al diésel —alrededor del 10 por ciento del precio final— que encarecen los traslados y, por lo tanto, obligan a internalizar a lo menos parte de los costos que un vehículo le causa al resto. Lamentablemente no hay estudios que hayan evaluado las consecuencias de estos impuestos y qué tan cerca están de los costos sociales de congestión y contaminación que causan los vehículos. 
dónde vivir y trabajar. Una vez que se cobre por usar las vías, cada uno debiera tomar sus propias decisiones. Por último, concluyen que aumentar la oferta de vías a medida que la demanda por traslados aumenta es una política sensata y apropiada.

¿A qué se debe la discrepancia entre estas conclusiones y la creencia muy difundida de que lo apropiado es castigar el uso del automóvil, forzar a que se use el transporte público y, en cualquier caso, no construir nuevas vías? Probablemente esto se concluye porque se supone que es apropiado minimizar el número de traslados y el flujo libre es lo ideal. Después de todo, es evidente que el tiempo dedicado a trasladarse es, en un sentido bastante preciso, perdido -muy pocos circulan sólo por el placer de hacerlo- Y Y también es cierto que cuando se construyen más vías y la gente circula más, la suma total del tiempo destinado a trasladarse aumenta.

Sin embargo, Cabrera, Díaz y Sanhueza explican que el costo de los traslados es sólo la mitad del asunto. La otra mitad es que la gente obtiene beneficios cuando se traslada. Y cuando se incluyen estos beneficios, ya no es apropiado concluir que se debe minimizar el tiempo dedicado a los traslados, porque para hacerlo es necesario dejar de hacer actividades valiosas. Al mismo tiempo, construir más vías, ampliar las existentes o aumentar su capacidad con una gestión mejor se justifica porque los aumentos de la demanda por traslados son consecuencia de nuevas actividades que producen beneficios. Esto es, después de todo, de sentido común. Muy pocos estarían dispuestos a decir, por ejemplo, que las sucesivas ampliaciones del mall Parque Arauco han sido un error, puesto que cada vez más gente compra ahí. De manera similar, suena peculiar afirmar que no se debe ampliar la capacidad de las redes telefónicas porque al final la gente hablará más. Por supuesto, la diferencia es que cuando se trata de transporte, las externalidades son muy importantes. Pero, precisamente, la finalidad de la tarificación vial es corregir la externalidad que causa cada vehículo. De ahí que una vez que se cobra por circular sea innecesario hacer mucho más ${ }^{28}$.

La tarificación vial puede sonar muy bien, pero ¿será oportuna y suficiente para impedir el colapso que muchos temen? Después de todo, el proyecto de ley que pretendía introducir la tarificación vial pasó años en el Congreso y nunca se aprobó. Cabrera, Díaz y Sanhueza son optimistas, pues creen que se puede introducirla a pesar de todo. De hecho, una buena parte del tráfico intercomunal se hace ahora por autopistas con peaje. Por supuesto, es más difícil justificar el cobro por vías que ya existen, pero se pueden mencionar tres condiciones que, de cumplirse, lo harían más acepta-

${ }^{28}$ Es importante notar que aumentar la capacidad de las vías se justifica aun sin tarificación, en la medida en que aumente la demanda por ellas. 
ble: los ciudadanos deben tomar conciencia del problema, los nuevos peajes debieran compensarse con disminuciones de otros impuestos y deben fijarse con criterios técnicos fáciles de entender. Por lo demás, cabe agregar que ahora se sabe que un sistema de cobro electrónico puede funcionar, tal como lo han demostrado las carreteras urbanas. Seguramente, es hora de pensar en sustituir los impuestos específicos a los combustibles por cobros electrónicos por el uso de las calles.

En todo caso, aun sin tarificación vial el colapso es lejano y posiblemente nunca ocurra. Con la entrada en servicio de las autopistas urbanas la capacidad vial aumentará mucho y, como muestran Cabrera, Díaz y Sanhueza (en Galetovic, ed., 2006, cap. 14), se mantendrá la velocidad promedio en la ciudad. Se suele creer que las autopistas urbanas concesionadas benefician sólo a quienes pueden pagar por usarlas. Pero Marcial Echenique (en Galetovic, ed., 2006, cap. 16) muestra que eso no es así. Todo lo contrario, los principales beneficiados son quienes no las usan y siguen circulando por las vías antiguas, porque en éstas la congestión será menor. A estos alivios debiera sumarse la mejora del transporte público con la entrada del Transantiago.

Por supuesto, en el mediano plazo el tráfico aumentará. Sin embargo, por las razones que se discuten líneas abajo en la sección III, es razonable pensar que en el futuro el empleo se va a desconcentrar y Santiago dejará de ser monocéntrico. Si así ocurre, el tráfico por los corredores radiales que conducen al centro debiera disminuir y el resto debiera dispersarse por toda la ciudad. Al mismo tiempo, el mayor desarrollo ocasiona que una buena parte del aumento de los viajes sea para llevar a cabo actividades distintas del trabajo y que tienden a ocurrir en forma más dispersa por la ciudad y en el día.

\section{LA REGULACIÓN, PLANIFICACIÓN Y GOBERNANZA DE SANTIAGO}

\section{III.1. Regulación urbana}

Alan Evans (en Galetovic, ed., 2006, cap. 10) explica que la regulación urbana se desarrolló durante el siglo diecinueve y principios del veinte en los países industriales. A diferencia de lo que ocurría en las aldeas campesinas que alimentaron a las grandes migraciones de la industrialización, las externalidades son inherentes a las ciudades, y fueron exacerbadas por el hacinamiento y la cercanía de las fábricas. La consecuencia fue una profusión de leyes, controles, reglamentos de planificación y ordenanzas de 
zonificación para disponer qué se podía hacer y dónde. Su finalidad era disminuir la densidad, alejar las fábricas y el resto de las actividades que causaban externalidades negativas de los lugares donde vivía la gente y crear espacios públicos donde se pudiera vivir una vida decente.

En principio, explica Evans, hay varias maneras de mitigar las externalidades. Por ejemplo, se les pueden cobrar impuestos a las actividades que las causan y, bajo ciertas condiciones, la negociación privada y los contratos entre vecinos son suficientes para corregirlas. Sin embargo, en la práctica se regula casi exclusivamente mediante controles y reglamentos impuestos desde arriba. Evans explica que esto se debe a razones históricas y a que políticamente es mucho más fácil imponer controles que cobrar impuestos.

Lucas Sierra (en Galetovic, ed., 2006, cap. 11) muestra que la regulación urbana chilena refleja este patrón, porque su sentido es "vertical": es decir, las normas son impuestas por órganos públicos —once ministerios con la preeminencia del Minvu - en vez de ser acordadas por las personas mediante el mecanismo más "horizontal” de los contratos. Así, en Chile la regulación urbana se sirve de normas imperativas o controles, tales como la zonificación, antes que de mecanismos destinados a incentivar acuerdos entre las personas como, por ejemplo, mecanismos tributarios o los derechos inmobiliarios transferibles.

Una de las conclusiones más importantes (y tal vez novedosas) de Sierra es que este ambiente regulatorio es hostil a los derechos de propiedad. En parte esto se debe a que las normas verticales han impedido el desarrollo de títulos o derechos que permitan la negociación privada en cuestiones urbanas. Pero, por sobre todo, la Ley de Urbanismo le da facultades tan amplias al Minvu que, en la práctica, el gobierno central puede alterar a voluntad los planos reguladores. Por ejemplo, el artículo $N^{\circ} 50$ de la Ley de Urbanismo le permite al Minvu modificarlos unilateralmente por razones de política habitacional. Y el ya mencionado artículo 55 le permite saltarse el límite urbano. El entonces Ministro de la Vivienda Jaime Ravinet resumió con franqueza y precisión el estado actual de las cosas con motivo de la polémica levantada hace un par de años por la construcción de una población de viviendas sociales cerca de la así llamada Comunidad Ecológica de Peñalolén, porque se requería aumentar de manera considerable las densidades de la zona afectada:

[Se] asegura que pretendemos modificar por decreto el Plan Seccional vigente y [se advierten] "múltiples consecuencias negativas para los vecinos de la Comunidad Ecológica”. Una aclaración fundamental: los planes seccionales no tienen vi- 
gencia eterna, como tampoco la tiene ningún otro instrumento de planificación urbana. Frecuentemente las comunas están introduciendo modificaciones para satisfacer las necesidades de la ciudad y de sus habitantes. Es más, el artículo 50 de la Ley General de Urbanismo y Construcciones establece que, en caso de vivienda social, se podrán hacer modificaciones a los planes reguladores que serán aprobadas por el Ministerio, previo informe del Municipio. Por lo tanto, las normas de un plan no constituyen un derecho adquirido por los propietarios, ya que está sujeto a las leyes nacionales que aseguran que no sobrepasen los derechos de los ciudadanos $^{29}$.

Sierra concluye entonces que en nuestro sistema jurídico la ley no establece derechos de propiedad a la hora de regular la ciudad: uno sólo es dueño de su casa y del terreno, no de las condiciones del barrio.

\section{III.2. La planificación urbana en Santiago}

Alan Evans (en Galetovic, ed., 2006, cap. 7) sostiene que los primeros urbanistas veían a la ciudad como una estructura física que los planificadores debían moldear para solucionar problemas, en esencia, físicos. Con el tiempo, sin embargo, se ha ido aceptando que las personas toman decisiones que los planificadores no pueden moldear a voluntad. La síntesis de estas dos visiones contrapuestas, explica Iván Poduje (en Galetovic, ed., 2006, cap. 9), es la así llamada planificación por condiciones. Poduje señala que ésta se sostiene en la premisa de que el crecimiento urbano sigue ciertos patrones casi inevitables, pero a la vez debe ser guiado por la planificación.

Regulación urbana y el debate sobre el límite urbano. El debate sobre Santiago puede entenderse en estos términos. De un lado están quienes creen que la expansión de la ciudad debe acotarse con el límite y moldearse mediante la regulación física de los usos del suelo. Del otro, los detractores del límite y zonificación, quienes los estiman indeseables porque restringen la libertad de elegir y la oferta de suelo. ¿Quién tiene la razón? Iván Poduje (en Galetovic, ed., 2006, cap. 9) sostiene que este debate ha sido en gran medida estéril y no se ha hecho cargo de la evolución de la ciudad real. Esto no significa que haya sido irrelevante, puesto que muchas

\footnotetext{
${ }^{29}$ Carta publicada en El Mercurio el 6 de agosto de 2003, p. A2. Las cursivas son nuestras.
} 
regulaciones se han impuesto con el afán de materializar sus visiones. Una de sus consecuencias ha sido una regularidad un tanto peculiar, a la que Poduje llama "el globo y el acordeón” y que se aprecia en su Plano 1, p. 234. El acordeón es el área que está dentro del límite que sucesivamente se expande (v. gr., en 1979 ó 1997) o contrae (v. gr., en 1975 ó 1994) según quién lleve las riendas del Minvu. El globo es la superficie urbana de la ciudad real, que crece todo el tiempo casi al margen de la evolución del límite.

Alexandra Petermann (en Galetovic, ed., 2006, cap. 8) documenta que, cualquiera haya sido su finalidad formal, el límite urbano no ha contenido la extensión de Santiago. En parte esto obedece a que, como ya se vio, el propio Minvu lo desplaza o sobrepasa cada vez que su política de vivienda social lo requiere. Pero también ocurre que, salvo durante episodios puntuales, siempre se ha dejado suficiente suelo sin urbanizar dentro del área de expansión urbana, aun en ocasiones en que formalmente la política ha sido restringir fuertemente la posibilidad de extender Santiago. Por ejemplo, Poduje muestra que el Plan Regulador Metropolitano (PRMS) de 1994, supuestamente muy restrictivo, en realidad no lo fue. Su Plano 5, p. 247, permite apreciar que el PRMS restringía el crecimiento de Santiago sólo hacia Calera de Tango, San Bernardo, Maipú, algunos sectores de La Pintana y en Pudahuel. Al norte y al oriente el límite replicaba casi con exactitud al de 1979, casi unánimemente señalado como liberal en extremo. Así, se dejaron alrededor de 22.600 ha para que la ciudad se expandiera, cuando Santiago cubría alrededor de 50.000 ha.

La zonificación también ha sido ineficaz. Nuevamente, en parte, se debe al peso de la política de vivienda social. Pero el problema de fondo es que se trata de normas incompletas e inapropiadas como instrumentos de planificación, porque regulan exclusivamente las inversiones que hacen otros - los privados, el MOP o el mismo Minvu cuando actúa como inmobiliaria-. Así, sólo sirven en comunas de alto atractivo inmobiliario (v. gr., Providencia), donde se puede materializar la imagen-objetivo de los planificadores regulando los usos, alturas y rasantes de los proyectos privados. Por contraste, es irrelevante en comunas que no son comercialmente atractivas - buena parte de las comunas centrales-, porque las normas físicas nada regulan si no se invierte ${ }^{30}$. Y en la periferia sin urbanizar, ámbito natural de esta regulación, prevalecen las presiones de las municipalidades, de las inmobiliarias y del propio Minvu.

${ }^{30}$ De hecho, Rodríguez y Winchester (2004), pp. 128 y 129, muestran que entre 1990 y 1998 más del 90 por ciento de las construcciones (medidas por el número de metros cuadrados aprobados) se ubicó ya sea en las comunas de la periferia, en la comuna de Santiago o en Providencia. 
Poduje advierte que la falta de instrumentos de planificación para intervenir en zonas ya construidas puede devenir en desastre urbano durante los próximos años. En Santiago hay unas 7.200 ha ocupadas por poblaciones de viviendas sociales (poco menos de un quinto de la superficie ocupada por residencias) que se irán haciendo progresivamente menos deseables a medida que aumente el ingreso de los hogares ${ }^{31}$. Lo natural en tal circunstancia es que las familias se cambien a mejores viviendas y el suelo se reconvierta. Sin embargo, es casi imposible reconvertir grandes paños porque la propiedad está muy dispersa — - sin los instrumentos de planificación apropiados, no hay forma de adquirirlas a costos razonables-. Así, seguramente se repetirá lo que ya ocurrió en muchas ciudades de países desarrollados: grandes áreas son abandonadas progresivamente y en ellas sólo quedan quienes no tienen dónde ir y siguen viviendo en condiciones de progresivo deterioro.

El límite y el precio del suelo. Desde hace más de 30 años se debate si el límite afecta al precio del suelo. Quienes se le oponen siempre han sostenido que restringe la oferta de suelo y aumenta su precio. Iván Poduje es escéptico por dos razones. La primera es que, como ya se vio, casi siempre el límite se ha fijado cuidando de dejar bastante suelo disponible para urbanizar. La segunda razón es menos evidente. Poduje argumenta que el precio del suelo en Santiago depende de la disponibilidad de suelo factible de urbanizar —aquel donde el negocio inmobiliario es rentable después de pagar por la extensión de las redes sanitarias, viales y de servicios-. Y en general el límite ha dejado espacio más que suficiente para acomodar la cantidad limitada de suelo adyacente a la superficie urbana que se urbaniza cada año.

¿Es Santiago anómalo? Después de todo, Alan Evans (en Galetovic, ed., 2006, cap. 7) argumenta que dondequiera se hayan impuesto límites a la expansión de las ciudades, los resultados fueron mayores precios del suelo, intensificación de su uso y prolongación de los viajes para ir a trabajar. Pero el mismo Evans da la clave para entender por qué Santiago no es anómalo, cuando señala que el efecto de un límite dependerá de su jerarquía legal y de la forma en que se aplique. Una misma regla formal, observa Evans, puede tener consecuencias muy distintas en diferentes países. Así, por ejemplo, desde que se impuso en 1947, el límite de Londres no se alteró, porque los reguladores fueron aislados de las presiones ${ }^{32}$. La consecuencia

${ }^{31}$ En 2002 las residencias ocupaban 38.307 ha.

${ }^{32}$ Más precisamente, en 1947 se impuso en Londres un cinturón verde, una franja verde de aproximadamente 400.000 ha que rodea a la ciudad y que no se puede urbanizar. 
ha sido que el suelo urbano es espectacularmente caro: el valor de una hectárea agrícola en la periferia de Londres se multiplicaría por 200 si el dueño obtuviera un permiso para construir viviendas. En Santiago, por contraste, existe una regla formal similar, pero el límite se modifica para responder a las presiones de los inmobiliarios y, sobre todo, a las necesidades del Minvu. En otras palabras, el precio del suelo no ha subido tanto porque, salvo contados episodios, en Santiago el límite no ha sido una camisa de fuerza ${ }^{33}$. La modificación del PRMS de 1997, que incorporó la provincia de Chacabuco al área urbanizable, es ilustrativa. A pesar de que duplicó la superficie urbanizable, los precios del suelo siguieron subiendo y sólo cayeron un año más tarde cuando la crisis asiática.

En definitiva, la relación entre límite y precio del suelo en Santiago requiere estudios rigurosos, y para ello es necesario abandonar la ideologización extrema que ha caracterizado a esta discusión. Por eso, mientras tanto, se trata de una pregunta abierta.

Planificación urbana y la ciudad real. Hay un hecho sorprendente que salta a la vista en el trabajo de Iván Poduje (en Galetovic, ed., 2006): el Santiago contemporáneo ha sido guiado y moldeado por un acto de planificación concebido y ejecutado durante los años cincuenta y sesenta desde la Dirección de Planeamiento del MOP, liderada primero por Juan Honold y Pastor Correa y luego por Juan Parrochia.

La influencia determinante del PRIS no se debe a que haya sido un acto de voluntad impuesto a la ciudad (aunque en cierta medida, por supuesto, lo fue), sino a que se planificaron y materializaron inversiones funcionales a la evolución de la ciudad real, en particular al aumento de la población desde poco menos de dos millones en 1960 hasta los 5,5 millones de hoy. Como ya vimos líneas arriba, el sistema de vías intercomunales permitió acomodar el crecimiento, sobre todo el de las poblaciones de vivienda social construidas en la periferia. Más aún, la influencia del PRIS de 1960 continuará sintiéndose por décadas, porque el plan de concesiones de autopistas urbanas es su continuación lógica.

¿A qué se debe la presciencia del PRIS? Del trabajo de Iván Poduje (en Galetovic, ed., 2006, cap. 9) se desprende que el plan fue resultado de un esfuerzo sistemático por entender la realidad urbana y las particularidades del crecimiento metropolitano. Por eso, se basó en conocimientos profundos, detallados y rigurosos de la realidad de Santiago, y éstos permitieron

\footnotetext{
${ }^{33}$ Poduje señala que en comunas puntuales sí lo es. Por ejemplo, sostiene que si se permitiera construir por encima de la cota 1.000, el precio del suelo en Las Condes caería.
} 
anticipar qué inversiones en transporte y vivienda pública serían necesarias en el futuro. Por eso se reservaron fajas de terreno para construir las futuras autopistas y se programaron las inversiones en ejes tales como las avenidas Norte-Sur, Dorsal, Pajaritos o Vicuña Mackenna.

Pero tan determinante como la rigurosidad del estudio previo fue que los planificadores captaron que el crecimiento acelerado de Santiago, que había comenzado durante los años cuarenta, transformaría su naturaleza. Santiago ya no sólo crecería en torno del centro tradicional, sino que se estaba transformando en una ciudad intercomunal y policéntrica que cubriría una extensión considerable y creciente. Así, resultaba crucial planificar y construir vías que comunicaran de manera fluida a los distintos subcentros y comunas del área metropolitana sin pasar por el centro histórico. Por lo mismo, no pretendió evitar que la ciudad creciera a toda costa, a pesar de que pretendía impedir que se ocuparan zonas agrícolas valiosas. Todo lo contrario, se partió de la premisa de que, con el correr del tiempo, localidades autónomas como Puente Alto, San Bernardo, Maipú o Quilicura formarían parte de la misma conurbación.

Y así lo ocurrido en Santiago desde mediados de los años cincuenta deja un par de lecciones sobre el ámbito y las posibilidades de la planificación urbana. El fracaso del límite y las normas de zonificación sugiere que es ineficaz planificar una imagen-objetivo física y espacial en una ciudad del tamaño y complejidad de Santiago. En el fondo, si bien se pretende imponer una imagen física desde el centro, en último término se descansa en las inversiones decididas por privados. Por supuesto, las reglas de zonificación deben existir, pero deberían decidirse a nivel local. Tal como lo señala Alan Evans (en Galetovic, ed., 2006, cap. 10), la mayoría de las externalidades que la zonificación pretende controlar no tienen impacto más allá de un área muy pequeña y limitada.

Por contraste, el desarrollo futuro de Santiago requiere de planificación central (o, si se prefiere un término menos cargado de emociones, metropolitana) cuando las decisiones de una comuna afectan a todo el resto. Evidentemente, es el caso de las vías intercomunales. Marcial Echenique explica (en Galetovic, ed., 2006, cap. 16) que el gobierno debe definir y planificar la red; fijar los peajes que simultáneamente la autofinancien y regulen la congestión; y expropiar la tierra necesaria para construir la infraestructura, a veces con décadas de anticipación. Pero más generalmente el Estado es responsable de una serie de inversiones que, finalmente, afectan a toda la ciudad. Es el caso, por ejemplo, de las inversiones en colegios, hospitales, viviendas sociales y de una serie de oficinas públicas. Hoy estas inversiones se planifican y ejecutan dentro del gobierno central, pero 
cada ministerio u organismo público responsable decide sobre las propias inversiones sin coordinación alguna. Por ejemplo, el plan regulador de 1994 del Minvu ignoró por completo no sólo al plan de concesiones de autopistas urbanas que por ese entonces diseñaba y ejecutaba el MOP; tampoco consideró las inversiones en viviendas sociales a cargo del mismo Minvu.

También se requerirán nuevos instrumentos de planificación para reconvertir los suelos que ocupan hoy las poblaciones de viviendas sociales construidas durante las últimas tres décadas. Éste será un problema metropolitano y por eso requerirá de soluciones diseñadas y coordinadas en ese nivel. Y, por último, una serie de actividades hoy a cargo de las municipalidades también requieren coordinación intercomunal ${ }^{34}$. Por ejemplo, ya vimos que los problemas causados por la basura se deben en buena medida a que no están bien definidos los derechos y obligaciones de cada comuna.

Hay otra lección que deja el PRIS de 1960: la planificación tiene impacto si se materializa en inversiones que, además, sean funcionales y coherentes con la ciudad real. Y si bien hace 40 ó 50 años tal vez era suficiente con que el Estado planificase así sus inversiones, porque era lejos el principal ejecutor de obras con impacto metropolitano, eso ya no es suficiente en el Santiago de hoy. En parte porque los privados están planificando y ejecutando inversiones con impacto metropolitano (v. gr., las Zoduc o las autopistas concesionadas). Pero también porque habría que planificar y reconvertir grandes extensiones de suelo ya urbanizado donde hoy apenas se invierte. En el futuro, por tanto, la planificación de las inversiones del Estado sólo debiera ser una parte de la planificación urbana. La otra parte debiera consistir en instrumentos que penalicen las externalidades negativas que causen las inversiones privadas y en incentivos para recuperar sectores deprimidos. Ésa es la planificación por condiciones.

¿Hacia la planificación por condiciones? Iván Poduje (en Galetovic, ed., 2006, cap. 9) sostiene que hacia fines de la década pasada cambió la forma en que se planifica y regula Santiago. El PRMS de 1994 fue abandonado en 1997 y, por primera vez, se permitió urbanizar suelo en la provincia de Chacabuco, al norte de Santiago. Esta ampliación del área de expansión urbana era distinta de la de 1979, porque ahora los grandes proyectos inmobiliarios - las así llamadas Zonas de Desarrollo Urbano Condicionado, Zoduc - tendrían que pagar por sus impactos ambientales y viales. Poduje estima que el acuerdo firmado por el MOP y el Minvu con nueve inmobiliarias en diciembre de 2001, y que selló el pago de alrededor de US\$ 70

${ }^{34}$ Una discusión al respecto se encuentra en Chuaqui y Valdivieso (2004). 
millones para financiar obras viales, marca el inicio exitoso de la planificación por condiciones.

La planificación por condiciones, explica Poduje, suprime el límite urbano tal como se le ha conocido hasta ahora, pues amplía de manera considerable el área sobre la cual puede crecer la ciudad. Sin embargo, crea normas que complementan a la zonificación y obligan a pagar por las externalidades negativas a quienes urbanizan nuevos suelos. Al mismo tiempo, la planificación por condiciones se sostiene en la premisa de que el crecimiento urbano es inevitable y deseable. Ahora se trata de orientar ese crecimiento mediante el trazado de la infraestructura básica, sobre todo la vial; de mitigar las externalidades negativas, y de reconvertir a las zonas postergadas.

Esto puede parecer un cambio radical y en gran medida lo es. Pero, por otro lado, no es más que ajustarse a la dinámica del crecimiento urbano con instrumentos apropiados. Aceptar que el crecimiento urbano es inevitable no es más que reconocer el efecto determinante que tiene sobre las ciudades el crecimiento del ingreso. Como ya se dijo, Marcial Echenique (en Galetovic, ed., 2006, cap. 3) muestra que cuando el ingreso aumenta, los hogares demandan más espacio para vivir y viajan más kilómetros. Al mismo tiempo, las ciudades pueden ser más prósperas porque las empresas ocupan más espacio y transporte. En efecto, las tecnologías de producción más avanzadas de manufacturas y servicios requieren más espacio y son más intensivas en traslados - la otra cara de la especialización y las economías de escala-.

El resto de los instrumentos se requiere por la dinámica que sigue el crecimiento urbano. Éste aparece primero como expansión, luego como densificación, para terminar con el cambio del uso del suelo. Se trata de un proceso dinámico cuyas características varían según los atributos del barrio o de la comuna donde ocurra. Por eso es necesario que los instrumentos y los procedimientos sean suficientemente flexibles y permitan esta transformación, controlen sus impactos y reconviertan a las zonas de la ciudad que van quedando rezagadas. Poduje indica que aún queda mucho por hacer, pues los instrumentos con que se cuenta son muy inapropiados.

\section{III.3. La gobernanza de Santiago y la “maraña” regulatoria}

Ya vimos que en Chile la regulación urbana es "impuesta desde arriba”. Pero ¿desde qué tan alto? Lucas Sierra (en Galetovic, ed., 2006, cap. 11) muestra que al tope de la pirámide casi siempre está el Presidente de la República, quien regula mediante su potestad administrativa. 
Una potestad normativa, explica Sierra, es un poder para dictar normas jurídicas. Por encima de la potestad administrativa están la constitucional y la legislativa. Sin embargo, desde hace más de 70 años en Chile las sucesivas leyes de urbanismo, de gobiernos regionales y de municipalidades le entregan casi exclusivamente al Ejecutivo la facultad de regular la ciudad y, en medida no despreciable, de gestionarla. El centralismo, la naturaleza enmarañada y desconcertante de la regulación de la ciudad y la subordinación de las municipalidades se pueden entender a partir de este hecho.

El pesado centralismo de la regulación urbana y la maraña normativa. Durante el siglo diecinueve las ciudades chilenas eran reguladas por leyes aprobadas en el Congreso y las municipalidades. Sin embargo, durante las primeras décadas del siglo veinte el gobierno central fue adquiriendo progresivamente mayor peso. En 1915 se le dio al Presidente la facultad de aprobar o rechazar los planos urbanos diseñados por los municipios, y de fijarles límites a las ciudades. Y en 1931 Carlos Ibáñez aglutinó las decisiones en la potestad administrativa del gobierno central dictando el DFL 345, la primera regulación general de urbanismo y construcciones, consagrando la facultad del Presidente para aprobar todos los planos reguladores y dictar la ordenanza general de la ley ${ }^{35}$. Desde entonces, la mayor parte de la regulación urbana ha sido administrada desde el gobierno central.

Una consecuencia es el carácter “enmarañado” (o, según Sierra, “selvático”) de la regulación urbana. Si bien buena parte de esta regulación es responsabilidad del Presidente de la República, éste delega en una legión de ministerios y otras organizaciones públicas. Así, cada potestad es ejercida por sus respectivos órganos titulares, dentro de un determinado ámbito de competencia y de acuerdo a un procedimiento preestablecido. Pero en cada caso concreto es habitual que más de una norma incida en la regulación del espacio urbano. Por ejemplo, muchas veces regula la ya citada Ley de Urbanismo, las leyes de medio ambiente, de pavimentación, de concesiones de obras públicas y varias otras. A todo esto se le suman las atribuciones de las municipalidades y de los gobiernos regionales. El resultado es una profusión de normas, el exceso de trámites, la escasa uniformidad entre ellos, mucha discrecionalidad por parte de las autoridades y frecuentes conflictos de atribuciones que no están normados ${ }^{36}$. Por eso es común escu-

\footnotetext{
${ }^{35}$ Un decreto con fuerza de ley (DFL) es una norma que tiene rango de ley pero es dictado por el Presidente previa autorización del Congreso.

${ }^{36}$ Chuaqui y Valdivieso (2004) describen los ámbitos en que se materializan estos conflictos de atribuciones.
} 
char historias de personas o empresas que se han paseado durante meses de un ministerio a otro tratando de completar una serie interminable y confusa de trámites ${ }^{37}$.

Obviamente, se necesitaría un diseño institucional muy sofisticado para coordinar fluidamente tal número de órganos del Estado y zanjar con celeridad los frecuentes conflictos de atribuciones. Pero si bien la maraña normativa es desconcertante, sería un error atribuírsela solamente al descuido o la desorganización del Estado. Una de las contribuciones más importantes del trabajo de Sierra (en Galetovic, ed., 2006, cap. 11) es mostrar que la locura tiene lógica, aquella que le imprime la potestad administrativa. En efecto, en último término la regulación urbana descansa en la voluntad del Presidente de la República, quien tiene autoridad para coordinar y zanjar conflictos de atribuciones. Por eso, no es una aberración, por ejemplo, que con cierta frecuencia se requiera reunir a dos o más ministros o incluso acudir al Presidente para zanjar un conflicto de atribuciones entre funcionarios de jerarquía menor. Es claro, sin embargo, que este mecanismo es ineficaz, pero también es muy difícil cambiarlo. Porque la solución sería que el Presidente delegue su facultad de zanjar conflictos en un órgano especializado y que se ate las manos al delimitar claramente las atribuciones de cada órgano del Estado dándole autonomía. Sin embargo, en gran medida esto implicaría renunciar a ejercer su voluntad y a darles atribuciones a terceros para que manden a los órganos del gobierno. Políticamente esto es inviable.

La subordinación del municipio. ¿Qué lugar ocupan las municipalidades en la regulación urbana? Pareciera existir cierto acuerdo en que es conveniente traspasarles atribuciones para descentralizar y "acercar las decisiones a la gente”. En 1991 se modificó la Constitución a propósito de los gobiernos comunales y regionales, y en los años siguientes siguió una serie de reformas legislativas. Gracias a estos cambios, las autoridades municipales de Santiago son elegidas y los municipios aprueban sus planes reguladores comunales y seccionales, mientras que el Consejo Regional (CORE) aprueba el Plan Regulador Intercomunal ${ }^{38}$.

A primera vista pareciera que hubo traspaso de poder desde el gobierno central hacia los municipios y los gobiernos regionales, porque antes los planes los dictaba el Minvu. Sin embargo, Sierra argumenta que este

${ }^{37}$ Una dificultad clásica ocurre porque la secuencia de los trámites es incierta. Por eso, suele ocurrir que dos ministerios sostengan que el trámite en el otro es anterior, lo que paraliza la gestión.

${ }^{38} \mathrm{El}$ plan regulador intercomunal es aquel que regula los usos del suelo en la ciudad. El plan comunal lo aplica en cada comuna, y el plan seccional detalla al plan comunal. 
traspaso es más aparente que real. Si bien la ley dispone que entre las funciones "privativas" de las municipalidades están la planificación y regulación de la comuna y confección del plan regulador comunal, también agrega que las municipalidades deben aplicar las disposiciones sobre construcción y urbanización sujetándose a las normas técnicas de carácter general que dicta el Minvu en ejercicio de su potestad administrativa. Por eso, una reforma de la Ordenanza de Urbanismo u otra norma administrativa "técnica” tiene el poder de modificar automáticamente un plan regulador comunal, seccional o metropolitano. Una cosa similar ocurre con el gobierno regional.

En realidad, la subordinación del municipio al Minvu también alcanza al día a día, porque el director de Obras de la municipalidad es, en los hechos, subordinado del Seremi del Minvu. En efecto, como indica Sierra, la ley ordena al Minvu "supervigilar" las decisiones que estos directores adoptan sobre construcciones y urbanizaciones, y opera como una suerte de segunda instancia frente a los reclamos que se hacen contra esas decisiones. Así por ejemplo, el Decreto Ley 1.305 de 1975, que tuvo por objeto regionalizar y reestructurar el Minvu, establece en su artículo 12:

Corresponderá a la División de Desarrollo Urbano: [...] Supervigilar el cumplimiento por parte de las Direcciones de Obras Municipales, de la Ley General de Construcciones y Urbanización y de toda otra norma legal o reglamentaria referida a la misma materia; [...] (j) Resolver en segunda instancia las reclamaciones interpuestas en contra de las resoluciones adoptadas por los Directores de Obras Municipales en asuntos relativos a la construcción y urbanización, siempre que la apelación sea fundada; (k) Autorizar a los Directores de Obras Municipales para postergar la concesión de permisos de construcción cuando está en estudio la modificación del Plan Regulador o su Ordenanza Local; (l) Supervigilar el cumplimiento, por parte de las Direcciones de Obras Municipales, de los preceptos contenidos en el D.F.L. 2, de 1959, y su Reglamento.

Cuestión adicional es que a lo menos diez ministerios más y numerosos organismos de gobierno tienen potestad sobre la ciudad. Por ejemplo, Iván Poduje (en Galetovic, ed., 2006, cap. 9, Gráfico Nº 3, p. 269) muestra que para aprobar un proyecto de desarrollo urbano condicionado (PDUC) se necesita la venia de una legión de organismos públicos. No sólo eso, sino que el proceso es descentralizado y cada uno de ellos puede vetar el proyecto, independientemente de lo que opine la municipalidad. Y, además de todo eso, la ejecución de muchos proyectos la realizan ministerios, sobre todo el MOP y el Minvu. 


\section{IV. ¿HACIA DÓNDE VAMOS?}

\section{IV.1. Sinopsis: crecimiento y expansión de Santiago durante los años noventa}

La excepción confirma la regla. Marcial Echenique y Gregory Ingram (ambos en Galetovic, ed., 2006) describen los patrones del desarrollo metropolitano — regularidades que aparecen en casi todas las grandes ciudades del mundo-. Aquí nos interesan cuatro:

Primero, si en las distintas comunas de un área metropolitana cualquiera se mide la densidad ajustada, se observará que en promedio ésta tiende a disminuir a tasa constante a medida que uno se aleja del centro. En esencia, las personas valoran la cercanía al centro porque ahí están los puestos de trabajo y están dispuestas a alejarse sólo si a cambio del mayor tiempo de traslado obtienen más espacio. Segundo, a medida que el país prospera y crecen los ingresos, tanto la densidad promedio como la diferencia entre la densidad del centro y de la periferia disminuyen ${ }^{39}$. Tercero, en todas las áreas metropolitanas los puestos de trabajo están más cerca del centro que las residencias ${ }^{40}$. Sin embargo, los empleos tienden a dispersarse a medida que crece el ingreso. Y cuarto, a medida que el empleo se dispersa, disminuye relativamente el tráfico por las vías radiales que conducen hacia el centro y los viajes al trabajo se acortan porque las personas que trabajan en la periferia tienden a vivir más cerca de su trabajo.

¿Qué tan pertinentes son estos patrones para entender el crecimiento y desarrollo de Santiago durante la segunda mitad del siglo veinte? Ciertamente, buena parte de los empleos se concentran en las comunas centrales. Por ejemplo, Andrea Tokman (en Galetovic, ed., 2006, cap. 17, Plano 2, p. 505) muestra que las comunas de Santiago, Providencia y Las Condes atraen a casi el 50 por ciento de los viajes al trabajo. Sin embargo, varios trabajos del libro Santiago: Dónde Estamos y Hacia Dónde Vamos sugieren que el Gran Santiago ha sido un tanto anómalo. Como ya se dijo y se puede apreciar en el Gráfico No 3, las densidades de las comunas no muestran relación sistemática con la distancia al centro. Así, por ejemplo, es posible encontrar comunas donde la densidad residencial sobrepasa los 200 hab/ha a casi cualquier distancia. Esta impresión se confirma con el Plano 7,

${ }^{39}$ Ambas regularidades fueron descubiertas por el inglés Colin Clark (1951). Marcial Echenique las explica en Galetovic, ed. (2006), cap. 3.

${ }^{40}$ Gregory Ingram resume este hecho de la siguiente manera: si se traza una línea divisoria imaginaria a distancia arbitraria del centro, el área que incluye al centro contendrá una fracción mayor del empleo que de la población urbana. 
de Iván Poduje y Alexander Galetovic (en Galetovic, ed., 2006, cap. 1, p. 22), que muestra la densidad ajustada de cada distrito censal. Si bien ésta disminuye notoriamente hacia el oriente, la mayoría de los distritos de la periferia sur y poniente son tanto o más densos que aquellos que rodean al centro ${ }^{41}$.

$\mathrm{Al}$ mismo tiempo, y tal como indica el Gráfico $\mathrm{N}^{\circ} 2$, la densidad ajustada de Santiago no ha cambiado mayormente durante los últimos 60 años. Y también se sabe que mucha gente pasa tiempos muy largos trasladándose entre su casa, generalmente ubicada en la periferia poniente o sur, y su lugar de trabajo, generalmente ubicado en el centro o en Providencia y Las Condes. No parece, por tanto, que los viajes se hayan acortado.

Sin embargo, la condición anómala de Santiago tiene una explicación simple: la política de vivienda social. Como ya se vio, durante mucho tiempo el Minvu construyó gran cantidad de viviendas donde el suelo era más barato, y por eso la densidad residencial es tan alta en la periferia poniente y sur. En gran parte pudo hacerlo porque Santiago contaba con vías intercomunales y microbuses más que suficientes que permitían trasladar a grandes números de personas hacia sus trabajos. Pero también porque castigaba fuertemente al beneficiario que rechazaba una vivienda ubicada inconvenientemente lejos. Andrea Tokman (en Galetovic, ed., 2006, cap. 17) explica que las familias postulantes a una vivienda encargada por el Minvu recibían una oferta que indicaba la ubicación de la población y la fecha de entrega. Si esta oferta no era aceptada en 15 días, la familia volvía a una lista de espera que, en promedio, duraba 15 años.

Por lo tanto, más que anómalo, Santiago es una excepción que confirma la regla. En efecto, Gregory Ingram (en Galetovic, ed., 2006, cap. 4) muestra que las excepciones en los patrones del desarrollo metropolitano aparecen en ciudades donde no hay un mercado inmobiliario. Éste era exactamente el caso de las viviendas encargadas por el Minvu, quien diseñó reglas que le permitían, en gran medida, ignorar las preferencias de los beneficiarios. No es muy sorprendente, entonces, que las comunas de la periferia sur y poniente sean anómalas. Por el contrario, Andrea Tokman (en Galetovic, ed., 2006, cap. 17, Gráfico $\mathrm{N}^{\circ} 3$, p. 503) muestra que la densidad cae rápidamente a medida que aumenta la distancia al centro en las siete comunas de ingresos altos, precisamente donde la expansión inmobiliaria estuvo a cargo de privados.

${ }^{41}$ Marcial Echenique (en Galetovic, ed., 2006, cap. 3) muestra que la densidad ajustada cae en promedio a medida que nos alejamos del centro si se consideran las 52 comunas de la Región Metropolitana. Las afirmaciones en el texto, sin embargo, se refieren a las 37 comunas del Gran Santiago. 
Y por eso es probable que, a pesar de todo, los patrones descritos por Echenique e Ingram sean una guía certera de lo que está por venir en las próximas décadas. Iremos un poco más allá y usaremos esos patrones para argumentar que la caída de la densidad ajustada durante los años noventa (desde 96,5 hab/ha en 1992 hasta 85,1 hab/ha en 2002; véase el Gráfico № 2) señala el comienzo de una tendencia de barrios periféricos menos densos y de caída general de la densidad ajustada —el camino que ya recorrieron las ciudades de casi todos los países desarrollados-.

Santiago durante los noventa. En más de un sentido la década de los noventa fue un período excepcional de la historia de Chile, y por cierto que tal adjetivo es apropiado para calificar al desarrollo económico. Durante el siglo veinte la economía chilena no creció rápido. Por ejemplo, desde la Gran Depresión de los años 30 hasta 1985 el PGB per cápita chileno aumentó en promedio apenas 1,1 por ciento por año. Pero a mediados de los años ochenta pasó algo extraordinario. A partir de 1986 y hasta 1997 la economía chilena creció 7,6 por ciento cada año. El PGB per cápita se duplicó y Chile avanzó en apenas 12 años lo que tomaba más de 60 a las tasas históricas. Los efectos sobre la ciudad fueron considerables.

Las consecuencias más notorias fueron el comienzo de la masificación del automóvil y aceleración de la ocupación del suelo. Enrique Cabrera, Carlos Díaz y Ricardo Sanhueza (en Galetovic, ed., 2006, cap. 14) muestran que el número de automóviles particulares se duplicó. María Elena Ducci y Marina González (en Galetovic, ed., 2006, cap. 5) muestran que la superficie urbana creció 12.049,9 ha entre 1991 y 2000 (véase también el Cuadro № 1). Este crecimiento en la periferia es aún más importante si se incluyen las parcelas de agrado que se masificaron hacia el norte y el sur de Santiago y cubrieron 5.000 ha, tal como lo documenta Iván Poduje (en Galetovic, ed., 2006, cap. 9).

¿Quiénes fueron los autores materiales de la expansión de Santiago? En términos gruesos, señalan María Elena Ducci y Marina González, un tercio de la ocupación de suelos nuevos se le debe a la industria y dos tercios a las viviendas ${ }^{42}$. Sin embargo, una de sus conclusiones más importantes es que sólo alrededor de un décimo del total del suelo nuevo, o la cuarta parte del que ocupan las residencias, se puede atribuir a las viviendas que fueron encargadas por el Minvu. En otras palabras, a esta altura ya

${ }^{42}$ Por supuesto, existen otros usos del suelo (v. gr., vialidad, equipamiento). Pero buena parte de éstos están destinados a servir ya sea a los hogares o a las empresas. 
no se puede decir que el Minvu es el principal autor material de la expansión del Gran Santiago ${ }^{43}$.

Por cierto, la disminución de la importancia relativa de las viviendas que encarga el Minvu no se debe a que se construyera menos. Tal como lo muestra Hidalgo (2005, p. 445), entre 1990 y 2002 el Minvu construyó poco más de 90.000 viviendas sociales, cifra que se acerca a las 105.000 y algo más construidas entre 1979 y 1989. Sin embargo, la actividad inmobiliaria privada creció mucho más rápido ${ }^{44}$. Y tan importante como la magnitud del suelo ocupado por viviendas "privadas" es el tipo de proyectos que emergió durante los noventa: grandes paños de terreno desarrollados por inmobiliarias que urbanizan el suelo, aseguran su conectividad y construyen los barrios cerrados, que describen en su libro Cáceres y Sabatini (2004) ${ }^{45}$.

Las inmobiliarias son más flexibles a la hora de elegir la ubicación de cada proyecto, porque pueden diseñar el barrio completo. Por eso aparecieron proyectos para hogares de ingresos altos en Peñalolén y Huechuraba, comunas donde el ingreso promedio es bajo; y también en comunas hasta ese entonces rurales como Colina en Chacabuco. Porque una vez que el automóvil se masifica, es menos relevante dónde está el proyecto. Así, la masificación del automóvil permite a las inmobiliarias elegir suelos más alejados del centro que son más baratos y ofrecer más espacio por el mismo precio. La consecuencia agregada es el crecimiento de la ciudad en barrios periféricos menos densos y la caída de la densidad en toda la ciudad — precisamente el patrón descubierto por Colin Clark en 1951—.

Si la disponibilidad de transporte y las vías de acceso influyen fuertemente en las decisiones de localización de los hogares, para la industria es determinante. Ducci y González muestran que casi todas las industrias se instalaron a lo largo de la Carretera Panamericana (en Lampa y Quilicura por el norte y San Bernardo por el sur) y alrededor de algunos tramos de la

${ }^{43}$ Con todo, el sesgo "perificador" sigue actuando y permanecerá con nosotros por un tiempo. Esto no sólo porque, tal como lo muestran Ducci y González, las viviendas sociales siguen concentrándose en el sur, el poniente y surponiente de Santiago, comunas con bajo equipamiento e infraestructura. Andrea Tokman (en Galetovic, ed., 2006, cap. 17) muestra que durante 2003 sólo el 20 por ciento de las viviendas encargadas por el Minvu se construyeron dentro del Gran Santiago. El restante 80 por ciento se ubicó más allá del límite urbano del Gran Santiago, en Buin, Colina, Lampa, Melipilla y Curacaví.

${ }^{44}$ Es importante notar que buena parte de la construcción privada es cofinanciada con subsidios habitacionales. Sin embargo, cuando el Minvu entrega un certificado, el beneficiario le compra su vivienda a un inmobiliario privado. En esos casos el ministerio no participa en la decisión de dónde localizar el proyecto.

${ }^{45}$ Más generalmente, se han masificado los condominios cerrados. Véase Hidalgo (2004) para un estudio detallado. 
avenida Américo Vespucio (en Quilicura y Pudahuel por el norte, y Maipú al poniente $)^{46}$. Esto confirma que, como ocurre en la mayoría de las grandes ciudades del mundo, las industrias siguen a las vías de acceso y no a los lugares de residencia de los trabajadores —más bien, son los trabajadores quienes siguen a las empresas-. De manera similar, aunque en forma incipiente, algunas empresas trasladaron sus oficinas a la periferia, también cerca de las vías intercomunales.

De esta forma, durante los años noventa el crecimiento de Santiago comenzó a parecerse mucho más al de las ciudades de países desarrollados. Pero aun así, ¿qué tan grandes son estos cambios y en qué medida marcan un quiebre de tendencia? Después de todo, la caída de la densidad ajustada desde 95,5 hab/ha en 1992 hasta 85,1 hab/ha en 2002 parece modesta.

Sin embargo, un pequeño detalle sugiere lo contrario. Porque si se mira el Cuadro $\mathrm{N}^{\circ} 1$ con cuidado se advierte que, por primera vez desde la década del cuarenta, la tasa de crecimiento anual de la superficie urbana es apreciablemente mayor que la tasa de crecimiento de la población —2,67 por ciento contra 1,39 por ciento- . La magnitud de la diferencia se aprecia en el Gráfico $N^{\circ} 5$. La curva celeste muestra la hipotética evolución del tamaño de Santiago desde 1992 y hasta 2052 si creciera lo mismo que la población entre los últimos dos censos, 1,39 por ciento cada año - es decir, manteniendo la densidad ajustada constante en los 96,5 hab/ha de 1992_; la curva azul muestra los resultados de un ejercicio similar, pero esta vez suponiendo que la superficie urbana crece como entre 1992 y 2002, 2,67 por ciento al año.

La evolución proyectada de Santiago en uno u otro caso es muy distinta. Nótese que si la superficie urbana hubiese crecido entre 1992 y 2002 a la misma tasa que la población, manteniéndose constante la densidad, Santiago habría cubierto en 2002 sólo 56.563 ha en vez de 64.125 ha. Y si las tasas de crecimiento de la población se mantuvieran durante este siglo, la diferencia se agrandaría con el paso del tiempo. Por ejemplo, al cabo de 30 años, en 2032, la ciudad cubriría sólo 85.583 ha si la densidad se mantuviera constante, pero 141.360 ha si creciera a la misma tasa que durante la década del noventa. ¿'Y qué ocurriría con la densidad si la diferencia de tasas de crecimiento se mantuviera por los próximos 50 años? En 2012 la densidad caería a 75 hab/ha, en 2032 a 58,4 hab/ha y en 2052 llegaría a 45,5

${ }^{46}$ Véase el Plano 4, de María Elena Ducci y Marina González (en Galetovic, ed., 2006, cap. 5, p. 138); y también el Plano 2, de Marcial Echenique (en Galetovic, ed., 2006, cap. 3, p. 88). 
GRÁFICO N 5: $\quad$ UNA EVOLUCIÓN PROYECTADA DEL TAMAÑO DE SANTIAGO

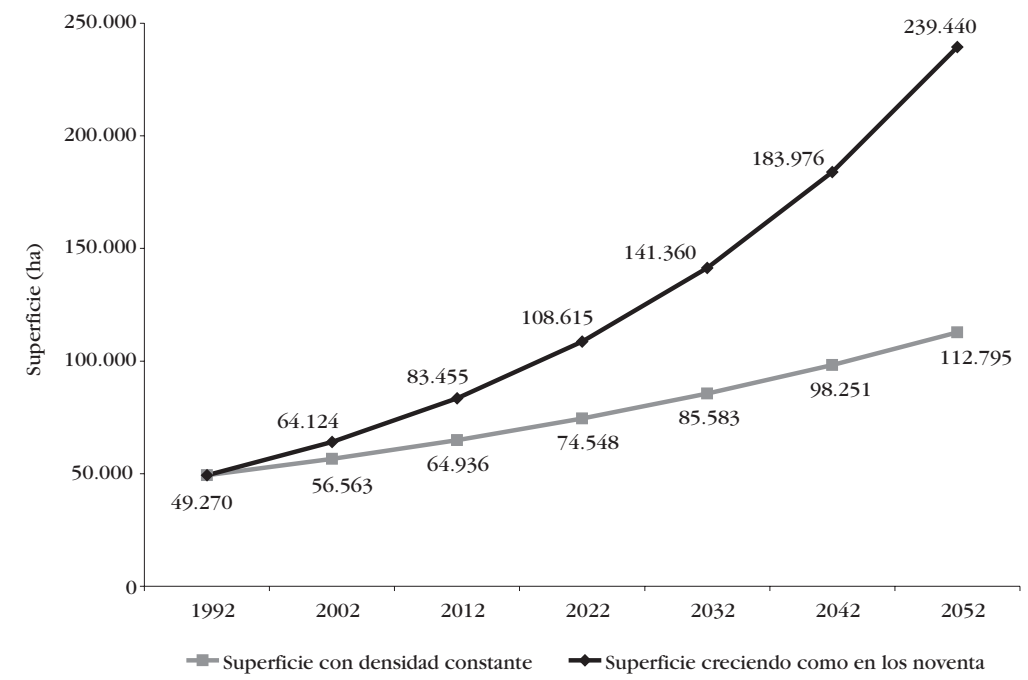

Notas: (1) La línea azul muestra el tamaño proyectado de la superficie urbana de Santiago si creciera 2,67 por ciento cada año. (2) La línea celeste muestra el tamaño proyectado de Santiago si creciera lo mismo que la población entre 1992 y $2002-1,39$ por ciento cada año-.

Fuente: Elaboración propia.

hab/ha. Se convergería entonces con los niveles de las grandes ciudades de los países desarrollados de Europa.

Por supuesto, éste es un mero ejercicio aritmético, que vale lo mismo que sus supuestos. Sin embargo es ilustrativo. Porque hay buenas razones para pensar que en el futuro previsible la población de Santiago no crecerá mucho más que el 1,39 por ciento por año de la década del noventa. De hecho, el INE estima que la población de Chile no crecerá más de uno por ciento por año durante las próximas décadas. Chile es un país urbano, por lo que la migración desde el campo no será muy significativa; y la fracción de la población urbana que vive en Santiago debiera, en el peor de los casos, mantenerse, pero incluso podría caer por las razones que se discutirán líneas abajo. Por eso, la evolución futura del tamaño de Santiago y su densidad serán determinadas principalmente por el crecimiento que alcance la economía. 


\section{IV.2. Desde área metropolitana hacia sistema urbano metropolitano}

Supongamos entonces que el crecimiento económico continúa durante los próximos 20 ó 30 años. ¿Cómo cambiará Santiago en el proceso? Ya no será más un área metropolitana y se transformará en un sistema urbano metropolitano como los de países desarrollados. Y, por eso, podemos mirar hacia esas ciudades para pronosticar lo que se avecina.

Diversidad y especialización. Ya vimos que las grandes áreas metropolitanas de países desarrollados son menos densas. Y el Gráfico $\mathrm{N}^{\circ} 5$ da una idea de cuánto más crecerá Santiago a medida que aumenten los ingresos. Pero tal descripción cuantitativa es insuficiente. El mayor tamaño y la menor densidad reflejan diferencias cualitativas que, a riesgo de simplificar más de lo conveniente, se pueden sintetizar con el binomio "diversidad y especialización”.

La mayor diversidad de bienes y servicios y la especialización de la producción son dos sellos del desarrollo económico. De un lado, la gente no sólo consume más a medida que crece su ingreso, también aumenta significativamente la variedad de los consumos y la demanda por servicios. Del otro lado, en un mercado más grande se puede producir a escalas mayores y aprovechar los beneficios de la especialización. Ambos factores se reflejan materialmente en las ciudades. Aparecen actividades, sobre todo servicios, que antes no existían; estas actividades y el empleo se esparcen por la ciudad y emergen distritos especializados que acogen a las firmas que producen cosas similares (v. gr., el distrito financiero en el centro, los barrios étnicos en el pericentro o las zonas industriales a lo largo de las autopistas de acceso a la ciudad).

Si Santiago sigue al resto de las grandes áreas metropolitanas de países desarrollados, su centro se especializará en aquellos servicios que exigen contacto cara a cara y comunicación eficaz — principalmente financieros, jurídicos y consultorías demandadas por las grandes empresas-. Pero "el centro" se extenderá más allá de las ocho manzanas alrededor de la Plaza de Armas por todo el corredor que parte en la Alameda, continúa por la avenida Providencia y termina en Apoquindo en el barrio El Bosque y aún más allá. El resto de los servicios debiera esparcirse por toda la ciudad, pues el comercio seguirá a los hogares. Esto ocurrirá porque los mayores ingresos permiten sostener volúmenes de ventas más altos —la escala dará para más que una sola gran área comercial en el centro-. Algo así ya se aprecia con los malls, que han proliferado por todo Santiago y seguirán construyéndose cerca de las autopistas urbanas. 
De manera similar, el empleo en manufacturas se desconcentrará, pero lo hará siguiendo de cerca a las autopistas urbanas que los harán accesibles. La demanda de estas industrias creará nuevos subcentros donde se ubicarán grandes comercios y oficinas, la mayoría en intersecciones con autopistas urbanas. Esto ya está ocurriendo en las intersecciones de la circunvalación Américo Vespucio con otras vías principales: en La Florida con Vicuña Mackenna; en Quilicura, con la avenida Norte-Sur, hoy autopista Central, o en Las Condes con la Avenida Kennedy y el mall Parque Arauco. La manufactura, por su parte, continuará ubicándose junto a los accesos de la ciudad.

Una de las consecuencias de la dispersión del empleo por toda la ciudad es que se comenzará a revertir la segregación entre empleo y residencias, hoy en día una de las características más notorias de Santiago. La diversidad y la especialización también cambiarán el crecimiento en extensión de la ciudad. Si hasta ahora Santiago ha crecido casi exclusivamente contiguo a la superficie urbana, en el futuro también aparecerá un sistema de asentamientos separados de la ciudad por espacios sin urbanizar. Ésta es, por supuesto, la suburbanización - la emergencia de comunidades que dependen funcionalmente de la ciudad, pero que están a cierta distancia sin formar parte de una conurbación- . De hecho, ya existe la forma legal que permite construir estas comunidades, los PDUC que describe y analiza Iván Poduje (en Galetovic, ed., 2006, cap. 9). Una vez que esto ocurra, se justificará decir que Santiago se ha transformado en una ciudad-región.

Habitando en Santiago: suburbanización, reciclaje urbano y vivienda social. La diversidad y la especialización también alcanzarán a las formas de habitar. Seguramente las tendencias más notorias serán la suburbanización y la expansión de la periferia contigua a la superficie. Las diferencias de ingreso y preferencias se reflejarán en los diferentes tipos de barrios privados, anticipados por los que ya se están construyendo por toda la periferia y en algunas Zoduc de Chacabuco. Pero, al mismo tiempo, también debiera masificarse el reciclaje urbano en el centro y en las comunas que lo rodean, tal como ya está ocurriendo en el sur de la comuna de Santiago.

El reciclaje urbano ocurre por varias razones, pero sus principales motores son el aumento del ingreso y los cambios demográficos. El mayor ingreso permite pagar el costo de reconvertir lo que existe o demolerlo. A cambio, las personas que se van a vivir al centro obtienen el beneficio de la vida urbana por antonomasia —el acceso a múltiples opciones y activi- 
dades sin necesidad de subirse a un auto-. Este tipo de vida es muy atractivo para hogares de una o dos personas, especialmente profesionales jóvenes y personas de más edad que ya no crían hijos. Y existe bastante acuerdo en que la población chilena envejecerá durante las próximas décadas y la edad del matrimonio continuará aumentando.

A estos motores del reciclaje se suman algunos desarrollos específicos de Santiago. Para comenzar, en casi todas las comunas que rodean al centro existen todavía paños de terreno grandes que se pueden reconvertir. En segundo lugar, ya se vio que una buena parte de las viviendas sociales básicas construidas durante los años ochenta y noventa debieran quedar obsoletas a medida que los hogares mejoren sus ingresos. Estos suelos, que según Iván Poduje suman 7.200 ha, podrían reutilizarse si se crean mecanismos que permitan superar la dificultad que implica poner de acuerdo a grupos grandes de pequeños propietarios ${ }^{47}$. Tercero, las carreteras urbanas han mejorado mucho la accesibilidad al centro. Por último, veremos líneas abajo que los espacios públicos debieran mejorar en la ciudad histórica para aumentar el atractivo de vivir ahí.

Con todo, sería un tanto ingenuo creer que el reciclaje detendrá o incluso retardará la expansión de la ciudad y la caída de la densidad. Después de todo, el mayor ingreso aumenta la demanda por espacio y éste cuesta menos en sectores más alejados del centro. Se trata de una tendencia general. Porque si bien se suele pensar que principalmente es cuestión de hogares que ya tienen ingresos altos, la realidad es que en buena parte se deberá al aumento del ingreso de hogares que hoy bordean la pobreza, pero que abandonarán esa condición de manera progresiva durante las próximas décadas. Puede que no impresione mucho el tamaño de las viviendas que hoy bordean las UF 1.000 y que se están construyendo masivamente. Pero son considerablemente más grandes si se las compara con las viviendas sociales básicas que progresivamente irán desapareciendo. De hecho, Marcial Echenique (en Galetovic, ed., 2006, cap. 3, Cuadro № 2, p. 82) estima que cuando un hogar sube desde el estrato socioeconómico bajo al medio, el espacio habitacional que ocupa se duplica.

Viviendo en Santiago: espacios públicos y calidad de vida. Las buenas ciudades de países desarrollados tienen mejor medio ambiente: aprovechan la geografía del lugar, los espacios públicos son atractivos, los parques y paseos abundan, la contaminación es baja y el ruido tolerable. El

${ }^{47}$ Valdés (1987) propuso hace casi 20 años un mecanismo con este fin para reconvertir al centro viejo. 
mayor ingreso permite gastar más y pensar mejor cómo gastar. Por eso, durante las próximas décadas vivir en Santiago debiera ser progresivamente más agradable.

La geografía y el clima de Santiago ofrecen muchas oportunidades. Alejandro Aravena (en Galetovic, ed., 2006, prólogo) describe el potencial del cerro San Cristóbal, que con una inversión pequeña podría transformarse en un paseo de escala metropolitana. Al mismo tiempo, señala Aravena, el clima es muy agradable: cuatro estaciones bien definidas, inviernos más bien cortos y no muy duros, un verano largo. Si hace calor, basta con ponerse a la sombra, pues la diferencia de temperatura entre sol y sombra, dado el clima seco, es notoria y notable. Esta diferencia abre una gran oportunidad para redistribuir bienestar, porque si las calles de Santiago se arborizaran masivamente - hoy el verde es atributo casi exclusivo del cono oriente de la ciudad—, buena parte de sus habitantes podrían disfrutar de esa diferencia.

El mayor ingreso permite gastar en conservación y espacios públicos. Por eso, los espacios públicos históricos deberían mejorar, y con ello los barrios que los albergan. Y, seguramente, también aparecerán nuevos espacios públicos y parques más modernos, algunos alejados del centro. De hecho, hay varias propuestas en marcha. Entre ellas se destacan nuevos parques metropolitanos en el Gran Santiago y la reserva de suelo para parques en los territorios de expansión, la recuperación como paisajes de los ríos y canales que atraviesan la ciudad y, quizás lo más relevante para el día a día de la mayoría, la obligación de reservar más espacio para áreas públicas y verdes impuesta a los proyectos de loteo y urbanización.

El mayor ingreso también genera un ciudadano más exigente que valora ese tipo de gastos y demanda que las obras de infraestructura y transporte incluyan respuestas adecuadas a los impactos esperados en el sistema de espacios públicos. Ejemplos son las propuestas para desarrollar el ex aeropuerto Los Cerrillos, el tratamiento paisajístico de la Costanera Norte, las propuestas urbanísticas y de espacio público para el río Mapocho, y la nueva Plaza Cívica frente a la cara sur del Palacio de la Moneda. En el futuro la preocupación por mejorar los espacios públicos y conservar el patrimonio, aún incipiente, pero que es fundamental para mejorar la calidad de vida urbana, debiera masificarse y diversificarse.

Al mismo tiempo, nada impide continuar disminuyendo la contaminación del aire. Como ya vimos, Ricardo Katz (en Galetovic, ed., 2006, cap. 12) muestra que aún quedan muchas oportunidades inexplotadas. Y, por cierto, los mayores ingresos justificarán gastar en tecnologías que cuestan más 
pero contaminan menos. Por lo mismo, es posible que con estándares más exigentes de calidad de vida se considere que el ruido es un problema. Si así fuera, se pueden esperar políticas que harán de Santiago una ciudad menos estridente e incluso un poco silenciosa.

Los cambios también debieran alcanzar a las instituciones públicas que gobiernan y gestionan la ciudad. Si lo que ha ocurrido en otros países ofrece alguna guía, las demandas crecientes obligarán al sector público a reorientar su acción hacia la supervisión y cumplimiento de condiciones de beneficio público, tales como medidas de seguridad, estándares de servicio más exigentes y justicia en los cobros por servicios. También debiéramos ver, crecientemente, asociaciones público-privadas para planificar, ejecutar y gestionar grandes proyectos urbanos. Y, de manera similar, asociaciones directas entre comunas que permitirán redistribuir los frutos del crecimiento. Por último, seguramente se comenzará a discutir sobre nuevos instrumentos de gestión muy diversos, desde los tributos locales dirigidos (tributos con destinos determinados) hasta las audiencias públicas donde se discutan los grandes proyectos.

Moviéndose por Santiago. Una consecuencia notoria y directa de la diversidad, la especialización y la suburbanización es el aumento del número de traslados. En parte se debe a que en una ciudad donde ocurren más cosas la gente se mueve más. Pero también a que la mayor producción requiere más espacio y traslados. Tal como lo señala Marcial Echenique (en Galetovic, ed., 2006, cap. 3), la movilidad es consecuencia, pero también causa, del aumento de los ingresos. En ese sentido se podría decir que las carreteras urbanas llegaron justo a tiempo ${ }^{48}$.

Se suele creer que la extensión de Santiago y el aumento de los traslados traerán congestión y contaminación crecientes, pero no necesariamente ocurrirá así. Como ya se dijo, Gregory Ingram (en Galetovic, ed., 2006, cap. 4) indica que con suburbanización y sobre todo con la dispersión de las actividades, los flujos de transporte se distribuyen en un área más extensa y disminuyen en los corredores radiales que conducen hacia el centro. La dispersión de las actividades también acorta los viajes, pues quienes trabajan en la periferia tienden a vivir más cerca de sus empleos y llegan a ellos más rápido. Algo de esto ha comenzado a ocurrir en Santiago con la entrada

${ }^{48}$ Tal vez se podría argumentar que las autopistas urbanas deberían haberse construido a principios de los años noventa. Pero, por otro lado, también es cierto que la tecnología para cobrar sin detener a los vehículos es muy reciente y posiblemente valió la pena esperar. 
en servicio de las autopistas urbanas. Por ejemplo, quienes viven en Vitacura o Lo Barnechea y usan la Costanera Norte llegan ahora mucho más rápido a Renca, Quilicura o Pudahuel, comunas periféricas en el poniente de Santiago, que a Providencia o Ñuñoa, comunas centrales.

La dispersión de las actividades también favorece a los medios de transporte más flexibles y exige la integración de los sistemas. De un lado, esto aumenta el atractivo de los automóviles más que del transporte público. Pero también requiere una gama más amplia de medios de transporte y frecuencias. Por eso, no sólo se trata de hacer eficiente el transporte en automóvil; el principal desafío de un sistema urbano metropolitano es articular y coordinar los distintos modos. Para ello, el transporte público debería desarrollar tarifas apropiadas, integrando los distintos modos y permitiendo que un mismo traslado ocupe más de un modo pero pagando un solo pasaje. No es necesario exagerar la importancia que tiene este cambio para que el sistema metropolitano funcione eficazmente.

Hay una consecuencia adicional del mejoramiento de las redes de transporte: quizás por fin comenzará a caer la primacía de Santiago como principal ciudad de Chile. Al menos así lo sugiere un estudio de Henderson (2000), quien encuentra que la población de países que disponen de una red densa de carreteras interurbanas habita en forma más dispersa. La razón parece convincente: las buenas carreteras disminuyen los tiempos de viaje y acercan a las ciudades. La distancia es menos importante y eso favorece la descentralización. En Chile seguramente el efecto será más fuerte en ciudades cercanas, tales como Rancagua, Los Andes o Valparaíso (particularmente beneficiadas por las autopistas urbanas que permiten entrar y salir rápidamente de Santiago), pero también será importante para las ciudades más alejadas. Así, es probable que ahora sea conveniente desconcentrar parte de las actividades que hoy se hacen en Santiago, sobre todo aquellas que se benefician con terrenos baratos y espacio abundante y no requieren estar cerca de los consumidores. Quizás la concentración de la población haya sido consecuencia de lo difícil que era llegar, entrar y salir de Santiago.

\section{IV.3. La necesidad de adecuar y mejorar las políticas públicas}

Uno de los tantos méritos del PRIS de 1960 fue captar que el crecimiento acelerado a partir de la década del 30 había cambiado la naturaleza de Santiago. En adelante ya no sería una suma de comunas, sino una ciudad grande. Y, por eso, con el tiempo sería perentorio construir vías que permi- 
tieran trasladarse sin pasar por el centro. Estas vías no podrían ser planificadas y construidas si cada comuna invertía por separado y de ahí la necesidad de la planificación intercomunal. La presciencia del PRIS permitió adelantarse a los cambios y ejecutar los proyectos a lo largo de más de 40 años a medida que las necesidades lo fueron requiriendo. El cambio desde área metropolitana hacia metrópoli o sistema urbano metropolitano es de similar novedad y magnitud, y también exige adecuar las políticas públicas. Pero el ajuste que se requiere hoy es distinto.

¿En qué consiste? Para apreciarlo conviene mirar desde dónde venimos. A riesgo de simplificar más de lo conveniente, se podría decir que hasta poco tiempo atrás ordenar el territorio y redistribuir ingreso para superar carencias básicas masivas eran las preocupaciones centrales (y, en gran medida, únicas) de las políticas públicas urbanas. No es posible explicar de otra forma, por ejemplo, el foco del Minvu en la cantidad de viviendas construidas, los énfasis del plan de descontaminación de emergencia que partió en 1990 o incluso la red de vías intercomunales del PRIS de 1960, diseñadas para evitar que el crecimiento monumental de Santiago impidiera trasladarse. Bien o mal hechas, las políticas públicas apropiadas en esas circunstancias son masivas y secuenciales.

Sin embargo, la combinación de crecimiento económico y políticas públicas bien diseñadas ha permitido superar buena parte de esas carencias básicas masivas y está cambiando la naturaleza de Santiago. La diversidad y especialización le exigirán al sector público atender múltiples demandas. Por ejemplo, hay que hacerse cargo de procesos de extensión, suburbanización y renovación urbana que ocurrirán todos al mismo tiempo, y cada uno demanda políticas distintas. A continuación argumentaremos que hay mucho trabajo por delante, porque el ajuste requiere cambios institucionales y legales profundos, modificar modos y costumbres y mejorar apreciablemente la gestión.

Planificación, inversión y gestión. A esta altura resulta casi un cliché que conviene descentralizar el gobierno de las ciudades y traspasarles atribuciones y recursos a los municipios. Por una vez, hay que decirlo, pareciera que el cliché es un acierto, porque todos hemos escuchado acerca de los defectos del centralismo. Por ejemplo, Sierra muestra que basta una simple decisión administrativa del gobierno para sobrepasar un plan regulador comunal. De manera similar, la ley regula detalladamente cómo debe construir su casa cada uno y relacionarse con su vecino. $Y$ aunque pocos lo 
saben, el responsable de tapar los hoyos de las calles es el intendente metropolitano, no el alcalde de cada comuna ${ }^{49}$.

Sin embargo, y a pesar de todo, muchas veces no se mejorará traspasándoles poder y recursos a las municipalidades. De un lado, Santiago no es una mera suma de comunas. Tal como se dijo líneas arriba y queda claro en los trabajos del libro Santiago: Dónde Estamos y Hacia Dónde Vamos, cuestiones muy diversas, tales como las redes de transporte o la ubicación de los vertederos de basura, son de dimensión intercomunal. Para que funcionen alguien debe tener autoridad suficiente para planificar a nivel intercomunal y luego imponerse al interés particular de cada comuna, invertir y supervisar el servicio. A pesar del centralismo y la verticalidad, la maraña que describe Sierra impide que esto ocurra.

Del otro lado, muchas de las dificultades actuales se deben a que la ley no deja espacio para los acuerdos entre privados porque es muy antigua y no reconoce que hoy la comunidad, los profesionales y los empresarios tienen gran capacidad para innovar. Un ejemplo son los proyectos de pavimentación. Aspectos tan sutiles como el ancho de un pasaje, el tipo de solera e incluso la definición de los espacios comunes viales en condominios son regidos por una sola autoridad, el Serviu, cuya capacidad de recoger propuestas del sector privado y municipal es muy limitada. Lo apropiado es dejar que los privados se pongan de acuerdo y tengan amplio espacio para adaptarse a las circunstancias particulares. La autoridad sólo debería garantizar que se cumplan las normas de seguridad y de bien común.

Con esto no queremos decir que sea inconveniente trasladar atribuciones y recursos a las municipalidades. Todo lo contrario, abundan las materias en las que esto sería deseable. Por ejemplo, las normas y planes de gestión e inversión locales debieran generarlos las municipalidades, quizás a través de corporaciones viales y de adelanto. Y no tiene sentido, como ocurre hoy, que toda pavimentación deba aprobarla el Serviu; o que para instalar un semáforo se requiera la venia del Ministerio de Transportes; o que el distanciamiento de las luminarias se regule con una norma única para todo Chile. Pero a pesar de todo, no se trata de elegir el punto óptimo en un continuo único entre centralización y descentralización. Algunas cosas hay que descentralizarlas, otras no. Y muchas otras habría que desregularlas. La talla única no sirve.

Seguramente cambios institucionales tan profundos requieren tiempo. Por el momento, y mientras la estructura se mantenga tal como la describe Sierra, es necesario coordinar las atribuciones que en el papel ejerce el

${ }^{49}$ Hasta principios de 2005 el responsable de tapar hoyos era el Serviu del Minvu. 
Presidente de la República, pero que en la práctica están dispersas entre una legión de organismos públicos del gobierno central. La prioridad debiera ser ordenar el guirigay de normas y atribuciones con que hoy gobierna, planifica y gestiona Santiago y las restantes ciudades de Chile. Con el tiempo hay que pensar instituciones nuevas y decidir caso a caso qué centralizar, qué trasladar a las municipalidades y qué dejar para acuerdos entre privados.

Información urbana y "accountability". Una de las principales dificultades que enfrentaron los autores que escriben en el libro Santiago: Dónde Estamos y Hacia Dónde Vamos fue obtener los datos necesarios para estudiar a Santiago. Esto no se debe, en general, a que estos datos no existan o a que no se gaste en generarlos. Todo lo contrario, los capítulos dan testimonio de que las instituciones de gobierno generan estudios e información abundante y detallada sobre Santiago ${ }^{50}$. Por ejemplo, el INE hace el censo, la Intendencia saca una foto aérea, la Sectra toma la encuesta de origen y destino. Al mismo tiempo, rara vez esa información es libremente accesible. Peor aún, las instituciones de gobierno ponen trabas para entregarla y muchas veces la venden a precios exagerados. Por ejemplo, el censo cuesta una pequeña fortuna, los datos de la Encuesta Origen-Destino se venden a precios negociados caso a caso, la encuesta Casen sólo está disponible a quien el Mideplán decida entregársela y por años el Minvu vendió el PRMS en dos millones de pesos, a pesar de que conocerlo era indispensable para cumplir con la ley. Estamos muy lejos de la costumbre en la mayoría de los países desarrollados: los datos financiados con impuestos se pueden obtener, sin pagar, en páginas web bien diseñadas.

Tal estado de cosas es lamentable, pues impide que investigadores independientes evalúen las políticas públicas y la gestión de las autoridades que las conducen. También es dañino, porque las decisiones que tomen los privados y las propias autoridades podrían ser mejores si pudieran estar bien informados. Por último, ocasiona el desperdicio de recursos, porque muchas veces los mismos estudios se hacen más de una vez. ¿Qué sentido tiene, por ejemplo, que cada municipalidad fotografíe su comuna desde el aire para confeccionar su plano regulador, cuando bastaría con que un solo organismo del gobierno central lo hiciera y expusiera los resultados en una página web?

Al mismo tiempo, las decisiones públicas no son transparentes. A veces, el problema son los procedimientos, que facilitan la toma de decisio-

\footnotetext{
${ }^{50}$ También dan testimonio del empuje y resolución de los autores.
} 
nes discrecionales (a veces arbitrarias) y en secreto. Por ejemplo, las votaciones del CORE no se publican y no se sabe quién votó qué. Pero más generalmente es muy difícil que las autoridades centrales, que son responsables de la mayoría de las decisiones locales, rindan cuenta.

La vivienda social. Por último, la política de vivienda social merece una mención especial. Ya consignamos sus logros, pero más conocidos son sus muchos defectos. No es el lugar para reformular esta política, tal vez la más importante de todas, pero los trabajos del libro Santiago: Dónde Estamos y Hacia Dónde Vamos que la estudian sugieren un par de modificaciones. Primero, hay que redefinir el rol del Minvu separando sus funciones de inmobiliaria y de regulador urbano en instituciones distintas; sólo así será posible evitar el conflicto de interés que ha marcado a la política de vivienda social por más de 50 años.

Segundo, si bien en la medida en que el ingreso crezca serán menos necesarias las viviendas básicas (hoy progresivas), la acción pública seguirá siendo necesaria. En esencia, hasta ahora la política ha consistido en producir una vivienda pequeña pero "completa”. Por contraste, se ha ignorado casi totalmente el entorno urbano. Esta decisión se ha justificado por la limitación de recursos, pero la consecuencia es que estas viviendas valen muy poco - tal como lo grafica Alejandro Aravena (en Galetovic, ed., 2006, prólogo), se parecen a un auto, que con el paso de los años vale cada vez menos-.

Tal vez la respuesta esté en repensar el desafío. En vez de producir una vivienda muy pequeña sin ciudad y que con el tiempo valdrá cada vez menos, quizás sea mejor entregar parte de una buena vivienda e invertir en la ciudad que la rodea. Hay dos razones que sustentan este enfoque. Por un lado, la inversión pública debiera resolver aquellos problemas que requieren decisiones colectivas. Si ponerse de acuerdo entre dos vecinos ya es difícil, más lo es coordinar a toda una cuadra; juntarse para arreglar el barrio es imposible. Ahí es donde se justifica la acción colectiva mediada por el sector público. Por otro lado, la capacidad de inversión de los hogares en sus propias viviendas es un hecho evidente. Una familia que recibe parte de una buena vivienda es capaz de completarla en un par de años. Todo esto debiera complementarse con el desarrollo de un mercado fluido de viviendas usadas y con instrumentos que permitan reconvertir el suelo ocupado por poblaciones irrecuperables por su progresivo deterioro.

¿Qué pasaría si no se mejoran las políticas públicas? El fantasma del imbunche. En su ensayo sobre Santiago, La Muralla Enterrada, Carlos 
Franz describe al imbunche, un personaje mitológico chileno “... cuyos orificios han sido cosidos y sus miembros amarrados o cortados para — sin matarlo - reducirlo a la inexpresividad total, a una pura posibilidad de lo que nunca será” ${ }^{51}$.

No es nuestra intención exagerar, pero la imagen del imbunche es útil si se trata de sintetizar a qué podría llegar a parecerse Santiago en las próximas décadas si no se mejoran las políticas públicas. Porque cada uno de los cambios descritos en la sección anterior requiere inversiones. Sin embargo, las políticas públicas actuales entraban, retardan y, en algunos casos, imposibilitan esas inversiones. Por ejemplo, las normas impuestas a los PDUC los encarecen a tal punto que se puede argumentar que los pueden dejar más allá de lo que el ingreso per cápita chileno permite pagar. Al mismo tiempo, muchos cambios requieren coordinar a un buen número de agentes y sin coordinación algunos problemas son muy difíciles e incluso imposibles de solucionar. Por ejemplo, los conflictos que causa la basura o la razón de por qué grandes extensiones de suelo no se reconvierten se pueden atribuir a la falta de instrumentos e instituciones que materialicen una coordinación eficaz. Es un hecho que Santiago va por delante y las políticas públicas están rezagadas. Si éstas no se mejoran y actualizan, los cambios descritos más arriba serán más lentos y algunos serán imposibles.

¿Y quiénes serían los damnificados por el imbunche? Es improbable que afecte demasiado a quienes tienen ingresos altos. Estos hogares siempre han sido capaces de pagar por sustitutos privados de los bienes urbanos que en otros países provee el sector público. Por contraste, los hogares con ingresos medios o bajos sufrirán las consecuencias del imbunche, porque para ellos organizarse es muy caro. Esto sería lamentable porque se perdería una magnífica oportunidad de redistribuir riqueza, pero sobre todo bienestar, a través del desarrollo urbano.

\section{CONCLUSIÓN}

Iniciamos estas páginas haciendo notar que, a juzgar por el tono en que se suele discutir sobre Santiago, parecería que las cosas van de mal en peor. En realidad, para muchos la crisis es permanente y el deterioro progresivo. Seguramente muchos se sintieron interpretados cuando el filósofo

${ }^{51}$ Franz (2001, p. 18) 
Martín Hopenhayn se preguntó en qué momento se desdibujó Santiago en el vértigo de la modernización descontrolada ${ }^{52}$.

El lector dirá, pero nosotros creemos que el cuadro que emerge a medida que se avanza por trabajos del libro Santiago: Dónde Estamos y hacia Dónde Vamos es un tanto distinto y justifica un optimismo cauteloso. El optimismo se debe a que en muchas dimensiones Santiago está bastante bien, más o menos donde cabría esperar, habida consideración de los 5.000 dólares de ingreso per cápita de Chile. Como vimos, en algunos casos esto se debe a mejoras apreciables alcanzadas durante las últimas dos décadas pero, en otras, a la planificación urbana hecha durante los años cincuenta y sesenta del siglo pasado. Además, muchos de los problemas de Santiago se resolverán en la medida en que el país crezca y se desarrolle.

Al mismo tiempo, existe amplio espacio para mejorar. En algunos casos se pueden lograr avances sustantivos con inversiones pequeñas, tal como lo sugiere Alejandro Aravena en el prólogo. En otros casos, sin embargo, se necesitan cambios legales profundos, inventar nuevos instrumentos de planificación o hacer estudios que hoy no existen. Por eso, la cautela obedece a que los desafíos son difíciles y requieren una mejora sustantiva de la calidad de las políticas públicas y de la planificación urbana. En resumen, el punto de partida dista de ser malo y nada indica que Santiago se aproxime a una crisis terminal. Pero al mismo tiempo hay muchísimo trabajo por delante, desafíos muy difíciles y algunos problemas aún ocultos pero que podrían devenir en desastres urbanos.

¿Por qué discrepamos de la imagen de Santiago en deterioro permanente? Una visión más optimista de Santiago es defendible por a lo menos dos razones. De un lado, varios trabajos del libro muestran que el crecimiento, extensión y caída de la densidad de una ciudad no sólo es inevitable sino que suele ser síntoma y consecuencia de cosas deseables. En particular, cuando aumenta el ingreso los hogares prefieren vivir en más espacio, y por eso compran automóviles y recorren distancias más largas. Tal como lo explican Enrique Cabrera, Carlos Díaz y Ricardo Sanhueza (en Galetovic, ed., 2006, cap. 14), a cambio de los traslados la gente obtiene cosas deseables que no se deben ignorar al momento de evaluar el crecimiento de la ciudad. Al mismo tiempo, la producción de bienes y servicios que causan esos mayores ingresos requiere más espacio y más traslados. La única manera de terminar con el crecimiento de Santiago sería acabar con el crecimiento de los ingresos. En el proceso se mataría la creciente diversidad y especialización de la cual podríamos beneficiarnos mucho.

52 Véase Hopenhayn (1993). 
Del otro lado, muchas veces la visión pesimista de Santiago se sostiene en creencias erróneas. A veces la situación es bastante mejor de lo que se cree. Así, por ejemplo, mucha gente cree que la contaminación del aire aumentó durante los años noventa y que sigue empeorando. La realidad, como vimos, es que disminuyó un tercio, a pesar de que, entre otras cosas, el número de traslados en vehículos motorizados creció más de 60 por ciento. Otras veces se afirma que en el resto del mundo ocurren cosas que no son tales. Por ejemplo, se suele afirmar que Santiago es más grande y menos denso que París o Nueva York. Sin embargo, en realidad ocurre lo opuesto: vimos que Santiago cabe más de diez veces en Nueva York, más de tres veces en París y es mucho más densa que ambas. Otras se desconocen logros innegables. Por ejemplo, con todos sus defectos, la política de vivienda social permitió que un número muy grande de familias obtuviera una vivienda sólida mucho antes de que sus ingresos lo permitieran. Gracias a esta política, casi el ciento por ciento de los hogares de Santiago tiene agua potable y luz eléctrica, el 92 por ciento está conectado al alcantarillado y ésta ha dejado de ser una ciudad con los problemas típicos de las ciudades grandes del tercer mundo. $\mathrm{Y}$ a veces ignoramos que algunas cosas se han hecho muy bien. Por ejemplo, la mayoría de nosotros cree que Santiago “jamás se ha planificado”. Sin embargo, el Santiago contemporáneo ha sido moldeado por un acto de planificación presciente concebido durante los años cincuenta y sesenta del siglo pasado y que continuará beneficiándonos por mucho tiempo más.

La discrepancia entre realidad y creencias cruza casi todos los trabajos del libro Santiago: Dónde Estamos y Hacia Dónde Vamos. Tal como lo señala Iván Poduje (en Galetovic, ed., 2006, cap. 9), esto no sería mucho más que una anécdota, si no fuera porque las creencias erróneas tienen influencia determinante sobre las políticas públicas y al final afectan al bienestar de millones. Por eso, establecer algunos hechos básicos sobre Santiago no es una cuestión de mero tono, forma o estado de ánimo. Es indispensable para que las políticas públicas se mejoren con la rapidez y profundidad que Santiago demanda. Los autores han hecho un esfuerzo detallado y sistemático por documentar con rigor esos hechos básicos; ya vendrán nuevos libros y trabajos con propuestas. Mientras tanto, el título que eligió Ricardo Katz para su trabajo sobre la contaminación del aire nos parece apropiado para resumir el cuadro que emerge del conjunto de estos estudios: Santiago está mejor que lo que creemos, pero a mitad de camino. 


\section{REFERENCIAS}

\section{Libro:}

Galetovic, Alexander (ed.): Santiago: Dónde Estamos y Hacia Dónde Vamos. Santiago:

Centro de Estudios Públicos, 2006.

TABLA DE CONTENIDOS:

Galetovic, Alexander: "Presentación”.

Aravena, Alejandro: "Prólogo".

Galetovic, Alexander e Iván Poduje: Cap. 1. “¿Quién es Santiago?”.

Echenique, Marcial: Cap. 3. "El Crecimiento y el Desarrollo de las Ciudades".

Ingram, Gregory K.: Cap. 4. "Patrones del Desarrollo Metropolitano: ¿Qué Hemos Aprendido?”.

Ducci, María Elena y Marina González: Cap. 5. “Anatomía de la Expansión de Santiago, 1991-2000”.

Balmaceda, Felipe: Cap. 6. "La Expansión de Santiago y la Hipótesis de la Demanda Excesiva por Infraestructura”.

Evans, Alan W.: Cap. 7. "Planificación, Cinturones Verdes y Límites al Crecimiento Urbano".

Petermann, Alexandra: Cap. 8. “¿Quién Extendió a Santiago? Una breve historia del Límite Urbano, 1953-1994”.

Poduje, Iván: Cap. 9. "El Globo y el Acordeón: Planificación Urbana en Santiago, 1960-2004”.

Evans, Alan W.: Cap. 10. "Externalidades, Planificación y Decisiones Colectivas".

Sierra, Lucas: Cap. 11. "Urbanismo por Decreto: Centralismo y Confusión Institucional en la Ciudad Chilena”.

Katz, Ricardo: Cap. 12. “Contaminación del Aire en Santiago: Estamos Mejor que lo que Creemos pero a Mitad del Camino”.

Zurita, Felipe: Cap. 13. “¿Nos Estamos Ahogando en Basura?”.

Cabrera, Enrique, Carlos A. Díaz y Ricardo Sanhueza: Cap. 14. "La Congestión en Santiago".

Díaz, Guillermo, Andrés Gómez-Lobo y Andrés Velasco: Cap. 15. "Micros en Santiago: De Enemigo Público a Servicio Público".

Echenique, Marcial: Cap. 16. "Las Vías Expresas Urbanas: ¿Qué tan Rentables Son?".

Tokman, Andrea: Cap. 17. "El Minvu, la Política Habitacional y la Expansión Excesiva de Santiago”.

\section{Otras referencias:}

Banco Mundial: World Development Indicators, 2004. Washington D. C.: Banco Mundial, 2004.

Cáceres, G. y F. Sabatini: Barrios Cerrados en Santiago de Chile: Entre la Exclusión y la Integración Residencial. Santiago: Instituto de Geografía de la Pontificia Universidad Católica y Lincoln Institute of Land Policy, 2004. 
Castañeda, T.: Combating Poverty: Innovative Social Reforms in Chile During the 1980s. San Francisco: International Center for Economic Growth, 1992.

Chuaqui, T. y F. Valdivieso: "Una Ciudad en Busca de un Gobierno: Una Propuesta para Santiago”. En Revista de Ciencia Política, 24 (2004), pp. 104-127.

Clark, C.: "Urban Population Density". En Journal of the Royal Statistical Society, Series A, 114 (1951), pp. 490-496.

Cummings, J. y D. di Pasquale: "The Spatial Implications of Housing Policy in Chile". En E. Glaeser y J. Meyer (eds.), Chile: The Political Economy of Urban Development. Cambridge: Harvard University Press, 2002.

De Ramón, A.: Santiago de Chile (1541-1991): Historia de una Sociedad Urbana. Santiago: Editorial Sudamericana, 2000.

Franz, C.: La Muralla Enterrada. Bogotá: Planeta, 2001.

Hack, G.: "Infrastructure and Regional Form". En R. Simmonds y G. Hack (eds.), Global City Regions: Their Emerging Forms. Londres: Spoon Press, 2000.

Henderson, V.: “The Effects of Urban Concentration on Economic Growth". En NBER Working Paper $\mathrm{N}^{\circ}$ 7503, 2000.

Hidalgo, R.: "De los Pequeños Condominios a la Ciudad Vallada: Las Urbanizaciones Cerradas y la Nueva Geografía Social en Santiago de Chile (1990-2000)”. En Eure, № 91 (2004), pp. 29-52.

Hidalgo, R.: La Vivienda Social en Chile y la Construcción del Espacio Urbano en el Santiago del Siglo XX. Santiago: Instituto de Geografía de la Pontificia Universidad Católica de Chile y Centro de Investigaciones Barros Arana, 2005.

Hopenhayn, M.: "Respirar Santiago”. En El Mercurio, agosto 15, E18, 1993.

Katz, R.: "Compensación de Emisiones: Un Instrumento de Alcance Global para el Control de la Contaminación Atmosférica”. Documento de Trabajo No 207, Centro de Estudios Públicos, 1993.

Kenworthy, J. R. e I. B. Laube: An International Sourcebook of Automobile Dependence in Cities. 1960-1990. Boulder: University of Colorado Press, 1999.

Lanfranco, P.: Muévete por Tu Ciudad: Una Propuesta Ciudadana de Transporte con Equidad. Santiago: LOM Editores y Ciudad Viva, 2003.

Martínez, J.: "Urbanización, Crecimiento Urbano y Dinámica de la Población de las Principales Ciudades de Chile entre 1952 y 1992”. En Revista de Geografía Norte Grande, 24 (1997), pp. 23-30.

Ministerio de la Vivienda (Minvu): Memoria Explicativa. Plan Regulador de Santiago. Santiago: Minvu, 1994.

Miranda, C.: “Expansión Urbana Intercensal del Gran Santiago 1875-1992”. En Estadística y Economía, 15 (1997), pp. 77-104.

Parrochia, J. y M. I. Pavez: El Plan Tridimensional de Ordenamiento Territorial y la Región Metropolitana de Santiago 1960-2000, segunda edición electrónica ampliada. Santiago, Facultad de Arquitectura y Urbanismo, Universidad de Chile, 2001.

Pavez, M. I.: "Orígenes de los Planes Regional, Microrregional e Intercomunal de Santiago, 1960-2000”. En M. I. Pavez (ed.), En la Ruta de Juan Parrochia Beguin. Santiago: Facultad de Arquitectura y Urbanismo, Universidad de Chile, 2003.

Pérez Rosales, Vicente: Ensayo sobre Chile. Santiago, Imprenta del Ferrocarril, 1859. 
Rodríguez, A. y L. Winchester: “Santiago de Chile: Una Ciudad Fragmentada”. En C. de Mattos, M. E. Ducci, A. Rodríguez y G. Yáñez (eds.), Santiago en la Globalización: ¿Una Nueva Ciudad?. Santiago: Ediciones SUR y EURE Libros, 2004.

Valdés, S.: "Remodelación Urbana para la Clase Media”. En Economía y Sociedad, No 63 (segunda época), 15-18, 1987. 